NBER WORKING PAPERS SERIES.

WHY ARE THERE SO FEW BLACK ENTREPRENEURS?

Bruce D. Meyer

Working Paper No. 3537

\author{
NATIONAL BUREAU OF ECONOMIC RESEARCH \\ 1050 Massachusetts Avenue \\ Cambridge, MA 02138 \\ December 1990
}

This project is related to work begun with Harvey Rosen and I have benefitted from numerous conversations with him. I would like to thank Rob Porter, Chris Udry, Paula Worthington, and seminar participants at the IRP Summer Workshop, the NBER Summer Institute, Northwestern, and Rice for their comments. Wayne Atkins and Robert Fairlie provided excellent research assistance, and Mark Holliday worked on this project as an independent study course under the author's guidance. I am also indebted to Al Nucci and David McMillen of the Census Bureau who answered numerous questions about the CBO and SIPP respectively. This project was supported by a University Research Grant from Northwestern University, and the NSF through SES-8821721. This paper is part of NBER's research program in Labor studies. Any opinions expressed are those of the authors and not those of the National Bureau of Economic Research. 
NBER WORKING PAPER \#3537

December 1990

\section{WHY ARE THERE SO FEW BLACK ENTREPRENEURS?}

\section{ABSTRACT}

Black entrepreneurship has been unsuccessful in the U.S. The fraction of employed blacks that work in their own businesses is about one-third that of whites. Other measures of success such as net income, number of employees, and form of organization show large differences between blacks and whites. This paper examines explanations for these differences, particularly focusing on the frequently cited economic explanations of liquidity constraints and consumer discrimination. Liquidity constraints are examined by estimating logit equations for who is self-employed in a cross-section and who becomes self-employed in a panel. These estimates suggest that net worth is not an important determinant of the racial differences in self-employment. An examination of small business starting capital indicates that little capital is needed to start most business and beginning entrepreneurs do not usually borrow. Examining the industrial distribution of black and white businesses, I do not find a greater relative representation of blacks in industries requiring less starting capital. I also examine if black businesses are relatively more common in industries where white customers more frequently patronize black businesses. Little support is found for this hypothesis. I conclude that cultural differences may explain black/white differences in self-employment, but this explanation requires further study.

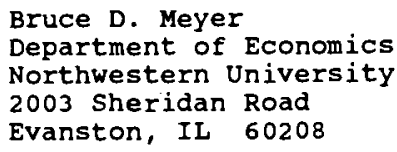




\section{Introduction}

Black entrepreneurship has not been successful in the United States. The 1980 Census indicated that 13.3 percent of employed white males worked in their own businesses, while 4.3 percent of black males did. Net income for black owned businesses is on average 35 percent of that of white male businesses. There are also enormous differences between black and white businesses in mean receipts and the number of employees.

These differences should be a source of concern for several reasons. First, self-employment. has been frequently proposed as a route out of poverty and is currently being promoted by many states and the federal government as a way to leave the welfare and unemployment insurance rolls. Second, it is often argued that self-employment provides a safety valve for those who are unable to obtain jobs elsewhere, due to discrimination, high unemployment, or other reasons. Third, small businesses are often perceived as a source of dynamism and growth in the economy. It is frequently argued that small businesses create a disproportionate share of new jobs and innovations. ${ }^{1}$ Fourth, small business owners have an important affect on political decisions in the U.S. ${ }^{2}$ The lack of black businesses means greater inequality in political power. Furthermore, the dearth of black businesses is behind the tensions between groups of blacks and ethnic store owners in many cities.

This paper begins by documenting the vast differences between blacks and whites in the number and earnings of entrepreneurs. The differences in self-employment rates are shown to be large using several independent data sources. I show that measures of success such as number of employees and business receipts are also very different for blacks and whites. I then examine explanations for these differences, focusing on the frequently cited economic explanations of liquidity constraints and consumer discrimination. Liquidity constraints are examined by estimating logit equations for who is self-employed in a cross-section and who becomes self-employed in a panel. These estimates suggest that net worth is not an important determinant of the racial differences in self-employment. Little capital is needed to start most business and beginning entrepreneurs do not usually borrow. Additionally, the industrial distribution of black and white businesses does not

\footnotetext{
${ }^{1}$ Brown et al. (1990) provides a critical analysis of the evidence.
}

${ }^{2}$ See Brown et al. (1990). 
indicate a greater relative representation of blacks in industries requiring less starting capital. Consumer discrimination can also be examined using the industrial distribution of black and white businesses. I examine if black businesses are relatively more common in industries where white customers more frequently patronize black businesses. Little support is found for this hypothesis. I conclude that cultural differences may explain black/white differences in self-employment, but this explanation requires further study.

\section{Liquidity Constraints}

Numerous authors have argued that low black assets and discrimination in lending have been responsible for low black self-employment rates. ${ }^{3}$ Blacks on average have very low assets relative to whites. Blau and Graham (1990) report that studies comparing the two groups find black/white asset ratios of .08 to .19 . Their own unadjusted ratio for households with a primary respondent age 24 to 34 in 1976 or 1978 is $.18 .^{4}$ These black/white ratios are strikingly low and suggest that the liquidity constraints hypothesis needs further investigation.

Several authors have emphasized the role of an individual's assets in the decision to become selfemployed. Examples are Evans and Jovanovic (1989), Evans and Leighton (1989) and Blanchflower and Oswald (1990). ${ }^{5}$ It has also been argued that limited access to credit has prevented minorities

\footnotetext{
(1988).

${ }^{3}$ Examples are Bates (1985a), Chen and Cole (1988) and Small Business Administration

${ }^{4}$ In the Survey of Income and Program Participation data, which include detailed questions about several dozen categories of assets and debts, I find a ratio of .21 for those households with head age 24 to 34 . For all households I find .26, a ratio which tends to rise with age (across cohorts) at least until age 65 .

${ }^{5}$ Blanchflower and Oswald (1990), which analyzes British data, is particularly interesting for two reasons. First, their measure of assets is gifts and inheritances so it is arguably exogenous to the decision to enter self-employment. Second, they find an effect of assets that is quantitatively large as well as being statistically significant.
} 
from starting businesses. An example of the small literature on lending discrimination and minority businesses is Ando (1988). ${ }^{6}$

Alternatively, Light (1972), Sowell (1981), and others argue that lending by formal institutions is not very important in the establishment of small businesses. They argue that people usually do not borrow to set up a business, and when they do, they mainly borrow from friends and relatives. Sowell argues that the degree of cohesion within a community will affect the ability to borrow. The lender needs to know that the borrower is worthy of credit (and maybe also be able to monitor the borrower's effort).

\section{Theories of Consumer Discrimination}

Many people have argued that low black self-employment rates are due to consumer discrimination, while others have suggested that consumer discrimination might be important, but have not necessarily endorsed the view that it is a primary cause. ${ }^{7}$ Consumer discrimination models have characterized some whites as being only willing to purchase a product from some blacks at a price lower than they would pay whites. Becker (1971) suggests that this type of consumer discrimination is likely to be important in retailing and the professions. He also argues that it is likely to be more important in jobs where there is substantial contact between blacks and whites.

In his survey, Cain (1986) argues that consumer discrimination is not important in explaining black/white earnings differences because blacks could easily find employment in jobs where there is little contact with consumers. This argument seems to be right for discrimination against wage and salary workers. However, the vast majority of the self-employed are sole proprietors who necessarily have substantial contact with customers. Thus, consumer discrimination might have a great effect on

\footnotetext{
${ }^{6}$ Ando (1988) finds that black men in her sample have a 12.8 percent lower loan acceptance rate, and black women have a 15.5 percent lower loan acceptance rate than nonminority men. However, this evidence is weak because the sample is small and highly unrepresentative. The data come from a sample which had a cumulative nonresponse rate (through two stages) of 97 percent.
}

${ }^{7}$ See Moore (1983), Chen and Cole (1988), and Borjas and Bronars (1989). 
the self-employed exactly for the reason it may have little effect on wage earners. One might expect consumer discrimination to be more important in industries where it is difficult to verify the quality of the product or service sold. In these industries, it is likely that prejudiced individuals would not obtain evidence to weaken their prejudices.

In a recent paper, Borjas and Bronars (1989) argue that the low black self-employment rate is due to consumer discrimination. They claim that consumer discrimination will lead more able whites and less able blacks to become self-employed. They argue that positive selection in an earnings equation for the white self-employed and negative selection for the black self-employed is a test of this hypotheses. The test is not completely convincing in that it depends on normal error terms and the exclusion of variables measuring the local labor market conditions from the wage equation. The test is also a general test of negative selection for blacks, rather than a test of consumer discrimination per se.

Coate and Tennyson (1989) make an argument similar to Borjas and Bronars. They claim that labor market discrimination can push lower ability minorities to find jobs as entrepreneurs. This lower quality will be recognized by the credit markets which will raise the interest rate charged to minorities when they borrow to start a business. They argue that in equilibrium, labor market discrimination can reduce the self-employment rate of minorities. They point out that their argument can also hold if consumers recognize the lower quality of minorities entering self-employment and lower the price they are willing to pay for their products.

On the other hand, many authors have argued that labor market discrimination will push those discriminated against into self-employment where an individual's return would depend directly on his or her ability. ${ }^{8}$ This argument is supported by anecdotal evidence about the history of Chinese and Japanese immigrants to the U.S. in Light (1972).

${ }^{8}$ See Light (1972), Sowell (1981), and Moore (1983), for example. 


\section{Data sources}

This paper primarily uses data from two sources: the 1984 Panel of the Survey of Income and Program Participation (SIPP), and the 1982 Characteristics of Business Owners (CBO). The Survey of Income and Program Participation is a longitudinal survey conducted by $\mathrm{U}$. S. Bureau of the Census. In the 1984 Panel, approximately 20,000 households $^{9}$ ( 50,000 people of all ages in total) were interviewed nine times over a three year period. ${ }^{10}$ The multi-stage stratified sample was selected to represent the noninstitutional population. The interviews took place between October 1983 and August 1986. Each interview asked about earnings and other income sources during the previous four month period. Detailed information was given about the two wage and salary jobs and two self employment jobs at which an individual worked the most hours during the survey period. Two supplemental surveys provide detailed information about assets and liabilities. Questions are asked about $\mathbf{2 0}$ types of assets and a dozen types of liabilities. The quality of the asset information is one of the key reasons for using SIPP."

The 1982 Characteristics of Business Owners data combines information from the Surveys of Minority-Owned Business Enterprises (SMOBE) and the Survey of Women-Owned Business (WOB) with information from a mail survey. SMOBE and WOB are a combination of IRS and Social Security Administration supplied information and Census Bureau Economic Census data. The IRS provides the Census Bureau with the name, address and employer identification number of the firm; social security numbers of the owners, partners or shareholders (up to 10 partners or shareholders per firm); principal industrial activity code; dollar receipts; and legal form of organization. The IRS does this for businesses filing forms 1040. Schedule C (sole proprietorships), 1065 (partnerships), or 1120 S (Subchapter S corporations). Using the social security number (SSN) from the IRS, the Social Security Administration supplies the racial information filled out when the individual originally applied for a SSN. Prior to 1981, applicants for a SSN would categorize their race as (a) white. (b) black,

'Budget cuts reduced the sample by about $20 \%$ halfway through the sample period.

${ }^{10}$ One-fourth of the sample was only interviewed 8 times.

"See U.S. Bureau of the Census (1986) for a description of the SIPP asset data. 
or (c) other. In 1981 the racial categories were expanded, but the Census Bureau used a mail canvas to obtain information on groups other than whites and blacks. The Census Bureau Economic Census files then provide the SIC code, geographic code, legal form of organization code, receipts, and number of employees and annual payroll for firms with paid employees.

This SMOBE and WOB data is supplemented by a mail survey sent to approximately 25,000 business owners in each of five panels: non-Hispanic white-male, black, women, Hispanic, and other minority. The sample was stratified by state, and 2-digit SIC. About eighty percent of those mailed surveys responded. ${ }^{12}$ The survey was sent out in 1986 but asks questions about 1982 . The survey contains detailed questions about starting capital, sources of funds, the fraction of customers and employees that are minorities, net income, length of ownership, age, sex, marital status, education, work experience, and other matters. The data cover all industries except

agricultural production, railroads, and public administration. Businesses with sales less than $\$ 500$, and businesses with more than nine partners or shareholders are also excluded. ${ }^{13}$ The micro data from the survey are not publicly available. The analysis below uses special tabulations by 2 -digit industry done under contract by the Census Bureau.

\section{Statistical Summary of Black and White Self-Employment}

\section{SELF-EMPLOYMENT RATES}

Blacks, other minorities and women all tend to have lower self-employment rates than white males. Table 1 gives self-employment rates from the 1980 Census of Population for several racial and ethnic groups, for both men and women. The self-employment rate is calculated as the fraction of all those working who are self-employed. The numbers in this table include agricultural selfemployment.

\footnotetext{
${ }^{12}$ See Nucci (1989), p. 12.

${ }^{13}$ See Nucci (1989).
} 
The black self-employment rate for males of 4.3 percent is less than ne-third that of whites which is 13.3 percent. The number for black women is also about one-third the figure for white women. Those of Spanish origin have self-employment rates about one-half the white rate, while Asians have self-employment rates similar to those of whites, with Asian women being self-employed at a higher rate than white women.

The numbers reported in Table 2, from the Surveys of Minority-Owned Business Enterprises and the Survey of Women Owned Businesses, suggest an even worse picture for black and Hispanic entrepreneurship. ${ }^{14}$ These numbers suggest that blacks are less than one-fourth as likely and Hispanics are less than one-third as likely to be entrepreneurs as white males. Table 3 presents analogous self-employment rates from the 1984 Panel of the Survey of Income and Program Participation. ${ }^{15}$ The SIPP numbers are sample counts rather than population estimates. I have excluded those working in agriculture and those not working full-time. An individual is classified as self-employed if he or she worked a majority of hours in self-employment. Most full-time workers had only self-employment hours or wage and salary hours and not both, as can be seen by the relatively small number of side businesses reported in Table 3.

\section{SELF-EMPLOYMENT EARNINGS}

Not only are there proportionately fewer black owned businesses than white ones, but those blacks who do become self-employed seem to fare worse than white entrepreneurs. This section describes the earnings of black businesses, while later sections analyze other measures of business success. Table 4 reports the number and mean net income before taxes of white-male, black and Hispanic owned businesses for 1-digit SIC industries. These

\footnotetext{
${ }^{14}$ The numerator of the self-employment rate is slightly different from that in Table 1 because agricultural production is excluded, and the numbers are a count of businesses so they include side businesses with receipts over $\$ 500$. The denominator also excludes those in the armed forces.
}

${ }^{15}$ These tabulations and all others below from SIPP exclude entirely imputed observations. 
comparisons unfortunately combine differences between blacks and whites and men and women. Even allowing for this, they suggest an enormous difference between the profits of black and white owned businesses, and less of a difference between hispanic and white owned businesses. Black businesses have net income about 35 percent of that of white-male owned businesses, while the comparable figure for Hispanics is 66 percent. The ratios differ greatly across industries with black/white ratios over 70 percent in construction and transportation and under 30 percent in agriculture, manufacturing, and wholesale trade.

Table 5 provides several summary statistics for white, black, and His panic self-employment earnings from SIPP. The exact measure of self-employment earnings used is given in the notes to the table. ${ }^{16}$ Comparisons of self-employment earnings with wage and salary earnings are hindered because comparisons tend to depend on what measure of central tendency is used. The comparisons are different depending on whether one uses mean, mean of log, or median earnings. ${ }^{17}$ The SIPP numbers on log earnings suggest that black and Hispanic earnings are similar or slightly better than those of whites in self-employment compared to relative earnings in wage and salary jobs. The standard errors are large given the small number of minority entrepreneurs, so that few conclusions can be drawn from the SIPP numbers. An analysis with the larger 1980 Census would be more definitive.

\section{EARNINGS REGRESSIONS}

\footnotetext{
${ }^{16} \mathrm{An}$ economic definition of self-employment earnings would be net income minus the interest rate times business equity plus the expected change in business equity. I have used the selfemployment draw earnings concept because net income was missing for almost half of the selfemployed. I did several tests for the data being missing at random, all of which failed. I plan to adjust reported earnings to accord more closely with an economic definition of the return to selfemployment.

${ }^{17}$ This points to the much greater dispersion of self-employment earnings than wage and salary earnings. In fact, calculating self-employment rates for each of the earnings deciles (selfemployment plus wage and salary earnings) for those working full-time in non-agricultural industries yields startling results. The self-employment rate for the lowest decile is 23 percent, the rate is 20 percent in the top decile, and 6 percent in between.
} 
Table 6 reports several earnings equations for both wage and salary workers and the selfemployed. The self-employed seem to earn much less than wage earners, with the gap even larger after controlling for individual characteristics. The self-employed tend to be older and more educated so that regression controlled estimates suggest that self-employment earnings are even lower. Compared to their wage earnings, blacks seem to do better in self-employment than whites, but the difference is not significant. The analogous comparison for Hispanics does suggest higher selfemployment earnings relative to whites and the coefficient is significantly different from zero. Other interesting coefficients include a significantly higher return to education in self-employment than in wage and salary jobs.

\section{OTHER MEASURES OF SUCCESS}

Table 7 reports other measures of the success of white, black and Hispanic businesses. The data indicate that black businesses have much lower receipts, fewer employees, and are less likely to be incorporated or be partnerships. These numbers accord with the general view that black entrepreneurship has not been very successful in the U.S.

\section{SIPP Micro Data and Liquidity Constraints}

This section analyzes data on individuals from the Survey of Income and Program Participation (SIPP) and asks if differences in individual attributes can explain the black/white differences in self-employment rates. Many authors have found that self-employed and wage and salary workers tend to have differing characteristics. For example. the self-employed tend to be older and more educated. This section examines whether these differences can explain the difference between the black and white self-employment rates. The section particularly focuses on black/white differences in net worth as an explanation for the differing self-employment rates.

Some suggestive evidence comes from the self-employment rates by net worth quartile. The rates from lowest net worth quartile to highest are 5.2, 7.0, 8.6 and 16.8 percent. The percentage of wage and salary workers in wave 4 who are self-employed one year later (wave 7 ) is from lowest to 
highest net worth quanile (wave 4) 1.8, 1.6, 1.7, and 2.2 percent. While the cross-section selfemployment rates suggest a relationship between net worth and self-employment, it is not clear what the causality is. The transition probabilities suggest that the relationship between net worth and entering self-employment is less pronounced.

I begin by examining a cross-section of individuals from Wave 4 of the 1984 Panel of SIPP. ${ }^{18}$ Table 8 reports estimates from several logit equations where the dependent variable is equal to one if an individual is self-employed and zero if he or she is a wage and salary worker. The sample for the analysis is all those working more than five hours/week; an individual is called self-employed if a majority of his or her work hours are in self-employment. A number of demographic variables such as age and education are included as well as measures of asset holdings. Assets are measured using two variables, net worth and net worth interacted with a dummy variable for the top net worth quartile. This specification is suggested by the self-employment rates by net worth quartile reported earlier. Those numbers indicated that the self-employment rate differs only slightly between the bottom three quartiles of the asset distribution, but rises dramatically in the top quartile. In most of the specifications, net worth excluding business equity is used as the assets variable because business equity is endogenous.

The estimates of Table 8 indicate that individuals who are more educated, older, married or previously married, and with young children are more likely to be self-employed. Blacks are estimated to be have a significantly lower self employment rate, and this coeficient is estimated precisely. The coefficient can be used to calculate the derivative of the self-employment rate using the distribution of explanatory variables in the sample. Using the estimates from specification (4), this calculation implies that the black self-employment rate is 7.36 percentage points lower than the white rate even after accounting for the other differences between blacks and whites. This estimated difference is

\footnotetext{
${ }^{18}$ Since several dozen questions are asked about assets, for example, I only exclude observations that are entirely imputed. If I exclude an observation because one asset item is imputed, I lose 30.4 percent of the observations used below in the transition logit equations. However, in this same sample, 97.2 percent of the observations have 3 or fewer imputed asset items out of 44 items.
} 
larger than the unadjusted difference in racial self-employment rates. Hispanics also have a significantly lower self-employment rate than whites. The asset variables are always significant, but the black indicator variable falls only slightly with the inclusion of assets in the specifications. Comparing specifications (2) and (3), one can see that the exclusion of business equity from net worth changes the coefficient on net worth dramatically, but the black indicator variable changes only slightly. These results suggest that differences in net worth do not explain the black/white selfemployment rate difference.

Another way to examine the importance of assets and other variables in explaining black/white self-employment differences is to substitute the explanatory variables for one group in a logit equation estimated on the other group. ${ }^{19}$ For example, one can estimate a logit equation on the white subsample and then calculate the mean predicted self-employment rate using the distribution of explanatory variables from the black sample. This calculation can be thought of as an estimate of the white self-employment rate if whites had the characteristics that blacks have, but their process determining self-employment did not change. Mathematically, let the probability that individual $i$ of race $\mathrm{j}$ is self-employed estimated from a logit model be $\left.\Lambda\left(x_{i j} \beta_{j}\right)=\exp \left(x_{i j} \beta_{j}\right) /\left(1+\exp \left(x_{i j} \beta_{j}\right)\right)\right)$, where $j=b$ for blacks and $w$ for whites. Then the estimated white self-employment rate if they are given black characteristics is $\Sigma_{i} \Lambda\left(x_{i b} \beta_{w}\right) / n_{b}$, where $n_{b}$ is the black sample size. This calculation can be thought of as performing the experiment of giving the black asset distribution as well as other characteristics of blacks to the white population and calculating the resulting self-employment rate assuming that the process generating white entrepreneurs does not change. If the resulting statistic is close to the self-employment rate in the black sample then it suggests that most of the difference between the black and white self-employment rates is due to differences in the characteristics of the whites and blacks in the data. If the resulting statistic is close to the white self-employment rate, it suggests that the process generating black entrepreneurs differs from that generating white entrepreneurs.

\footnotetext{
${ }^{19}$ This type of exercise is described extensively in Cain (1986). Here I have used the distribution of explanatory variables for a racial group rather than the mean, as the two methods will differ in a nonlinear model.
} 
The reverse calculation can also be performed and is equally valid. ${ }^{30}$ The statistic $\Sigma_{i} \Lambda\left(x_{i w} \beta_{b}\right) / n_{w}$ can be interpreted as the predicted black self-employment rate if blacks are given the characteristics that the sample of whites has. but the process generating black entrepreneurs does not change. Similarly, if this statistic is close to the white self-employment rate it suggests that most of the differences in self-employment rates can be attributed to differences in the characteristics of the white and black samples. If the statistic is far from the white rate it suggests that whites and blacks have different processes generating entrepreneurs.

Both sets of statistics for each of the first four specification are reported at the bottom of Table 8 along with the raw self-employment rates in the sample for each race. Using specification (3), the statistic with black characteristics indicates that about 31 percent of the black/white difference can be explained by individual characteristics. However, only 4 percent of the difference is explained by net worth, which one can see by comparing specifications (1) and (3). The statistic using white characteristics indicates that about 53 percent of the difference is due to individual characteristics, with about 38 percent of the difference attributable to net worth differences. This approach yields conflicting results, because one method implies that assets explain little, while the other indicates they explain about 38 percent of the difference between blacks and whites. ${ }^{21}$

The derivative of the self-employment probability with respect to assets that is implied by the logit estimates is also very small. Using specification (3), the estimates imply that giving $\$ 100,000$ (almost 1 1/2 times mean net worth excluding business equity) to each person would only raise the self-employment rate by .69 percentage points.

\footnotetext{
${ }^{2}$ It has been argued that the reverse calculation is more appropriate because policies to change black characteristics are more plausible than policies to change white characteristics. However, the choice is analogous to an index number problem so that both statistics are equally valid in principle. One or the other calculation may be preferred because it has a smaller sampling variance.

${ }^{21}$ The reason for this discrepancy is clear upon examination of the white only and black only specifications in columns (5) and (6) of Table 8. The white coefficient on net worth is negative, while the black coefficient is large and positive. One might want to discount the results using the black net worth coefficient because the coefficient is not precisely estimated.
} 


\section{TRANSITIONS TO SELF-EMPLOYMENT}

There is a good reason to not base conclusions on the cross-sections described above. It is likely that household asset holdings are endogenous. The cross-sectional correlations between selfemployment and assets found above may be an indication that the self-employed are more able to accumulate assets rather than an indication that assets are crucial in enabling a person to become self-employed. An approach which eliminates much of this endogeneity is the examination of transitions into self-employment. Longitudinal analyses have the advantage of using past values of individuals' characteristics such as assets to explain transitions. We can be more confident that past values are a cause rather than a consequence of being self-employed. There still may be some endogeneity of assets if a person saves to enter self-employment.

The logit equations are estimated over two time periods. Most of the analysis concentrates on transitions between the end of 1984 and the end of 1985 , a one year period. ${ }^{2}$ The analysis is repeated for a longer interval between the end of 1984 and the middle of 1986, a 20 month transition. $^{2}$ The sample consists of those who are wage and salary eamers in period $t-1$, and either self-employed or wage and salary workers in period t. ${ }^{24}$ About 1.9 percent of wage and salary workers are self-employed one year later. This percentage rises to 2.3 percent if one looks over the longer 20 month period.

Tables 9 and 10 report estimates from a number of specifications of the logit transition equations. The effects of most demographic variables in the transition equations is very similar to their effects in the cross-sectional analysis. The more educated, older workers, males, and married people are more likely to enter self-employment. A change from the cross-sectional results is that young children decrease the transition rate and the effect of being previously married is smaller, but

\footnotetext{
${ }^{2}$ I am able to match 87.27 percent of the observations in Wave 4 to data in Wave 7.

${ }^{3} \mathrm{~A}$ change in the rotation group pattern causes this to be a twenty month transition for three-quarters of the sample, and a sixteen month transition for the last quarter of the sample.

${ }^{24}$ The sample analyzed is restricted to individuals who worked more than five hours per week in both periods.
} 
these effects are not pronounced. Again, blacks and Hispanics are estimated to have lower transition rates.

Several different alternatives for the way net worth affects transitions are tried. These specifications include net worth entered linearly, net worth with a different slope in the top net worth quartile, net worth interacted with age, and net worth split into five asset categories. In none of these approaches does net worth explain an appreciable fraction of the difference between the black and white transition rates. The coefficient on the black indicator variable changes only slightly when the different measures of net worth are included. In specification (3) of Table 9 the coefficient implies that the black transition rate is 1.11 percentage points lower than the white rate after accounting for net worth and other individual characteristics. This difference is exactly the same as the comparison of mean transition rates without accounting for individual characteristics.

Again, an alternative way of measuring the importance of net worth and other explanatory variables is the calculation of the predicted transition rate for blacks when their characteristics are substituted in the logit equations estimated using the white only sample. The reverse exercise cannot be performed here with much confidence as the black sample is too small to estimate separate coefficients precisely. Specification (1) of Table 9 indicates that 36 percent of the difference between the black and white transition rates can be explained by a small set of demographic variables including age, education, and marital status. Comparing specifications (1) and (3) one sees that the addition of net worth only increases the explanatory power of individual characteristics to 39 percent. The other specifications yield similar results. Again, differences in net worth do not appear to be an important explanation for the self-employment differences.

The derivative of the transition rate with respect to net worth that is implied by the logit estimates is also very small. Using specification (3), the estimates imply that giving $\$ 100,000$ (almost $11 / 2$ times mean net worth excluding business equity) to each person would only raise the transition rate by .00077 .

Table 10 reports some results on the importance of other variables in the transition rate logit specifications. Specifications (5) and (6) suggest that those entering self-employment previously had 
low earnings but worked long hours. Specification (6) suggests that those that have previously worked in a small business are more likely to start their own business. Not surprisingly, the specification also indicates that union members and those who have held the same job for a long time are unlikely to start a business. ${ }^{25}$

\section{INIERPRETING THE RESULTS}

The interpretation of the reduced form transition equations raises several questions. Saving to enter entrepreneurship might bias the coefficient on net worth upward. Consider a situation where everyone is identical, except that some people save to enter self-employment. Then the net worth coefficient will be positive in a transition equation, but by assumption everyone has the same ability to accumulate assets and enter business. If people only borrow to enter self-employment, then the asset coefficient will be zero, unless assets are used as a criteria for giving a loan. As will be shown below, a majority of entrepreneurs do not borrow to begin their businesses. Thus the second argument does not seem to be of great importance.

Additional evidence that may explain why net worth has little effect on self-employment transitions comes from data on changes in household asset portfolios when entering self-employment. The data indicate that most of these businesses have low equity and assets, and individuals do not usually borrowed money to establish the business. I examine the portfolios of the 241 people who are wage and salary workers in Wave 4 of the 1984 SIPP panel. and are self-employed one year later. The 4th percentile of change in business equity upon entering self-employment is zero, the $71 \mathrm{st}$ percentile is $\$ 10,000$. The 44 th percentile of the change in business value is zero, the 70 th percentile is $\$ 10.000$. The $72 \mathrm{nd}$ percentile of change in business debt is zero, the 85 th percentile is $\$ 10,000$.

\section{BUSINESS FAILURES}

\footnotetext{
${ }^{2}$ The variables added in specification (6) are taken from Wave 3 and pertain to the main job held during the four months previous to Wave 4 . 1 have implicitly assumed that individuals held the same job at that time. Because some observations did not match Wave 3, the sample size is smaller in specification (6).
} 
I have concentrated above on the black white differences in transitions to self-employment. The SIPP data indicate that blacks are only 43 percent as likely to transit to self-employment as whites, while the analogous level of black self-employment is 35 percent of that of whites. This suggests that while most of the difference in self-employment rates is due to a lower business formation rate, part of the difference is due to a higher black business failure rate. ${ }^{26}$ This section analyzes the determinants of exit from self-employment using several logit specifications.

Table 11 reports estimates from a logit model for exit from self-employment. The sample is all those individuals who are wage and salary workers in Wave 4, but are self-employed one year later in Wave 7. The dependent variable is 0 if an individual is still self-employed eight months later in Wave 9, and 1 if the individual is not working or is a wage and salary worker in Wave 9. These equations thus provide estimates of the short run failure rate for recently started businesses.

Specifications (1) and (2) classify an individual as wage and salary or self-employed on the basis of where he or she worked the most hours. Specification (3) investigates if the results change when one includes only those individuals who only have wage and salary hours in Wave 4 and only self-employment hours in Wave 7. In all of the specifications, most variables enter with the expected signs, but the sample is too small to estimate the race variables with any precision. The results are informative, however, on the issue of assets. The net worth coefficient is always small and insignificant. The implied derivative from specification (1) indicates that giving $\$ 100,000$ in net worth to each self-employed individual would only lower the failure rate from .307 to .300 . Again, it does not appear that assets play a central roll in the ability to be self-employed.

The sample size for the business failure logit equations is too small to be informative on racial differences in failure rates, but the evidence from other studies suggests that the black failure rate

\footnotetext{
${ }^{26}$ If one fits a first-order homogeneous Markov chain to the data by using the one year transition rates for whites and blacks in Table 9, and the self-employment rates from Table 8, one obtains an implied failure rate for whites of .173 and .232 for blacks.
} 
is similar to that of other groups. ${ }^{77}$ Thus, the evidence indicates that most of the difference in black/white self-employment rates is due to transitions to self-employment.

\section{7. СBO Industry Data, Liquidity Constraints and Consumer Discrimination}

In this section, I analyze the liquidity constraints and consumer discrimination hypotheses using the Characteristics of Business Owners data. The data indicate that most businesses require only a small amount of capital to open and that their owners rarely borrow. This confirms the lack of importance of assets in the logit equations and the small changes in portfolios following entry into self-employment found in Section 6. I also find that blacks are not overrepresented in industries that require little starting capital or in those industries where whites frequently patronize black businesses.

\section{AMOUNTS AND SOURCES OF CAPITAL}

Table 12 reports the starting capital that was needed by the business owners in the CBO sample. The exact question is:

What was the total amount of capital YOU needed to start or become an owner of this business? Capital includes your own assets, money that was given to you, and money you borrowed. ${ }^{23}$

The most striking thing about the numbers in Table 12 is that the amount of capital needed to start a business tends to be small. 63 percent of nonminority males responding and 78 percent of blacks responding indicated that they needed less than $\$ 5,000$ to start their business. Note that this is the starting capital of a cross-section of existing firms, not a sample of entering firms. Thus, it will heavily weight successful firms.

\footnotetext{
${ }^{7}$ Using the Survey of Minority-Owned Enterprises. Stevens (1984) finds that the failure rates of black. Hispanic and Asian businesses differ only slightly over a five year period. Bates (1989) examines the largest quarter of the CBO businesses and finds that black owned firms had a slightly higher failure rate.
}

${ }^{28}$ The respondent chose from nine possible categorical responses such as None, $\$ 1-4,999$, $\$ 5,000-\$ 9,999$, etc. 
One might wonder how one can start a business with such small amounts of capital. However, it seems plausible that a small-scale contractor would begin by renting equipment, an insurance salesman would not need any capital, and a peddler would need little. One might argue that some businesses may need cash over a long period of time. Presumably respondents would account for this in their answers. Furthermore, a small businessman can use cash flow to finance further expansions and it is unlikely that a business will need a lot of capital later just to operate if it needs little to begin. Lastly, if black businesses are hindered by an inability to obtain subsequent capital, then they should have a much higher failure rate which is not the case.

Despite beginning with little capital, these enterprises are worth studying. To be in the sample, a business had to have at least $\$ 500$ in receipts. If the CBO includes a large number of marginal enterprises, then its universe estimates should be much greater than those from other sources. A comparison of the $\mathrm{CBO}$ number of businesses as reported in Table 2 to the number of people in Table 1 or 3 that are primarily self-employed indicates that the CBO numbers are only slightly larger than the Census estimates (which do not include side businesses) and are the same or smaller than the SIPP estimates including side businesses. Furthermore, if these businesses are marginal enterprises it is even more surprising that minorities are not overrepresented. Lastly, the $\mathrm{CBO}$ responses on hours worked indicate that most of these businesses required a great deal of their owners' time. 64 percent of the white-male business owners worked more than 30 hours/week in their business and 72 percent worked more than 20 hours/week.

Table 12 reports the percentage of starting capital that was borrowed, and Table 13 reports the sources of borrowed capital and equity capital. The numbers indicate that generally capital is not needed or an individual uses his or her savings. Banks are not a key source of funds, and neither are family members. 


\section{SELF-EMPLOYMENT BY 2-DIGIT INDUSTRY}

Table 14 reports the number of black and white-male owned businesses in each 2-digit SIC industry, as well as the mean value of several characteristics within each industry. The percentage of firms with less than $\$ 5.000$ in startup capital comes from the "starting capital needed" question described above. The percentage less than $\$ 5.000$ was chosen rather than the mean because for many industries at least one of the capital size categories was suppressed due to Census confidentiality requirements. The percentage of firms needing less than $\$ 5,000$ to start provides a measure of the financial hurdle an individual faces when considering opening a business in the industry.

The columns for percentage of firms with primarily minority customers needs further explanation. The CBO question asks "During 1982, what percentage of the customers served by your business were White and NOT of Hispanic origin?" Seven different percentage ranges were given as possible responses. Again, because many industries had the frequency of at least one possible response suppressed due to Census confidentiality requirements, the percentage of firms that had at least 50 percent minority customers was used as the summary statistic.

\section{LIQUIDITY CONSTRAINTS}

The liquidity constraints/low assets explanation for low black self-employment rates suggests that there will be relatively more black businesses in industries where a large percentage of businesses need less than $\$ 5.000$ in initial capital. This suggests a positive slope to the relationship between the ratio of the number of black businesses to the number of white-male businesses and the percentage of black businesses with startup capital less than $\$ 5.000$. Figure 1 is a graph of this relationship for 1-digit SIC industries. ${ }^{-9}$ A positive relationship is not evident in these points. Figure 2 is the

\footnotetext{
${ }^{29}$ Missing values limit the sample to a subset of the SIC's in Table 10 . All nonmissing values are shown in the table.
} 
analogous graph for 2 -digit SIC industries. Again, there does not appear to be any relationship. Since Figure 2 is dominated by the outlier SIC 41, local and interurban passenger transit, Figure 3 reproduces the graph excluding SIC 41. Again, there does not appear to be a relationship between the relative number of black businesses and the starting capital needed in that industry. Figures 4 and 5 are analogous to Figures 2 and 3 , but they use the percentage of white-male owned businesses that needed less than $\$ 5,000$ starting capital. Again. there is no apparent positive slope that would be predicted by the liquidity constraints/low assets explanation for low black self-employment. Regression estimates of the relationships in these graphs are in Table 15 and are discussed below.

A possible deficiency of this analysis is that starting capital may not include funds an individual needs to support himself or herself while a business is being started. While, the opportunity cost of time is presumably lower for blacks on average given lower wage and salary earnings, lower savings might be an impediment not captured by starting capital requirements. A second difficulty is that a 2-digit SIC is an aggregation of many activities. For example, SIC 41, which is mainly taxicabs, has a moderately high entry cost if one buys a car, but a fairly low one if one leases. In some cities the cost of legal entry is high because of the expense of a taxicab medallion, while in others it is essentially free.

Additionally, the ability to use capital as collateral for a loan may differ across industries. This problem is probably not very severe as most small businessmen are not entering specialized industries where their capital could not be used as collateral. Lastly. the industry distribution of black businesses is likely to be influenced by minority set-aside programs. However, the available information on these programs is insufficient to determine if they have a profound effect on the number of firms, and how the effect varies across industries. ${ }^{30}$

\footnotetext{
${ }^{30}$ See Bates (1985b) for a description of preferential treatment programs.
} 


\section{CONSUMER DISCRIMINATION}

This section provides evidence on the plausibility of consumer discrimination as it is typically formulated. I take consumer discrimination to mean that some whites are only willing to patronize some black businesses if the price charged by the black businesses is less than that of white businesses. I also assume that this discrimination will be more pronounced in some industries than in others. This difference could occur because the distaste whites have in shopping at black businesses may depend on the type of business, because the type of contact will vary. Alternatively, industries might differ in the ease with which the quality of the product can be verified. In those industries where the quality is not easily verified, prejudice might be more likely to persist.

I measure the degree of consumer discrimination in an industry by the percentage of black businesses that indicate that their customers are at least half minorities. If the black businesses have mostly minority customers, I assume that whites are unwilling to shop there because of consumer discrimination. I take this approach because it is ditficult to objectively classify industries as to whether or not there is a high degree of customer contact, whether the customer contact is objectionable to someone discriminating, and whether it is difficult to verify the quality of the product. Therefore, I have used the degree to which the business attracts white customers as an objective measure of consumer discrimination.

Figures 6 through 9 plot the black/white-male ratio of the number of businesses against the percentage of black businesses that indicate that their customers are at least half minorities. Consumer discrimination implies a negative relationship between these two variables. If black customers also discriminate against black business owners, or black businesses are able to cater to black tastes better (clientele effects) then one might not expect to see the hypothesized relationship. Figure 6 is the 1-digit industry graph. while Figures 7 and 8 display the 2-digit relationship with and without SIC 41 (taxicabs). None of these graphs show the negative relationship predicted by 
consumer discrimination. For comparison, Figure 9 graphs the black white-male number of business ratio against the percentage of white-male businesses with primarily minority customers.

One might be concerned that the primarily minority customers variable strongly reflects geographic location. Most of the industries examined are retail or service industries and are local businesses. If these black businesses are unable or unwilling to locate near white neighborhoods then it suggests that they feel they will not find white patrons. If they are only able cater to blacks, then the consumer discrimination hypothesis implies that their market would be limited and they would not prosper.

Table 15 reports a series of regressions which test the visual impressions of the figures using the 2-digit SIC data. The dependent variable in all cases is the logarithm of the black/white-male ratio of the number of businesses. Regressions using two samples are reported because each sample has its advantages. The first sample is the full sample, and the second excludes SIC's with fewer than 500 black businesses and fewer than 10,000 white businesses. The full sample suffers from some measurement error in the right-hand-side variable because it is a group average, with the degree of measurement error depending on the number of businesses. The subset of industries excludes the most mismeasured observations, but introduces some bias because of truncation determined by the dependent variable. I do not expect that either bias will be pronounced, but as a check I have reported both sets of estimates.

The regression estimates in Table 15 do not provide much support for either the liquidity constraints or the consumer discrimination hypothesis. The coefficients on the starting capital variables do not generally have the expected positive sign. and the minority customer coefficients do not generally have the expected negative sign. The only coefficient that is of the expected sign and almost significant is the white starting capital coefticient in Specification (2) for the full sample. For 
these equations I also performed heteroskedasticity tests which failed to reject homoskedasticity in 8 of 9 cases by a wide margin. ${ }^{31}$

An additional set of graphs examine if the effect of liquidity constraints and consumer discrimination is more evident in the ratio of black to white-male net income by industry. Without the micro data only a 1-digit SIC industry analysis can be presented. Figures 10 through 12 are graphs analogous to those above, but they display relative net income rather than the relative number of businesses. These graphs seem to fit the theories somewhat, with the starting capital graphs showing the expected positive slope if one excludes transportation, and the minority customers graph showing the expected negative slope.

\section{Other Explanations}

Several other explanations for the low rate of black entrepreneurship have been proposed. Two of these explanations might be called the consumer demands explanation and the culture of entrepreneurship explanation. Kinzer and Sagarin (1950). Glazer and Moynihan (1970), and Light (1972) all describe special demands of various ethnic and racial groups that were served by entrepreneurs from that group. Examples are exotic vegetables that Chinese immigrants sold to each other, Kosher wine and matzos that Jewish entrepreneurs sold to other Jews, and pasta that Italians sold to their former countrymen. These special consumer demands provided business opportunities that were not easily filled by members outside the group. It is argued that blacks had very few special consumer demands that could not be satistied by white entrepreneurs.

There are several difficulties with this consumer demands theory. First, it does not explain the success with which Chinese and Japanese immigrants seem to have been able to sell to those

\footnotetext{
${ }^{31}$ I regressed the square of the OLS residuals on a constant and the variance in the dependent variable obtained using unpublished $\mathrm{CBO}$ standard errors and the delta method.
} 
outside their group fairly soon after their arrival in the U. S. ${ }^{32}$ Second, businesses catering to special consumer demands may provide a captive market, but it is a small one. Today such businesses must make up an even smaller percentage than they did in the past. For this explanation to continue today it requires a great deal of persistence in group entrepreneurship patterns.

The second explanation is that blacks have lacked a culture of entrepreneurship. Frazier (1957) has talked about a "lack of [black] traditions in the field of business enterprise." Glazer and Moynihan (1970) have argued that as slaves, blacks did not have a tradition of managing money, and that this has hindered attempts at entrepreneurship. Related to this argument is evidence suggesting that many people learn about entrepreneurship from friends or relatives. The difficulty with this explanation is that it can approach a tautology. The explanation also requires these trends persist over long periods of time, which may not be plausible given the high rate of small business turnover.

In a series of books and articles, Light ${ }^{33}$ has tried to add more substance to the Frazier argument by describing cultural and class characteristics that aid entrepreneurship. He describes informal capital markets, usually rotating credit associations, that aided entrepreneurship among Chinese, Japanese and Korean immigrants. He also emphasizes ways that the tight knit nature of the these groups supported entrepreneurship. Business development was aided by ethnic solidarity, mutual support networks, nepotistic hiring, informal and formal restraints of trade, and language barriers according to Light. He also argues that recent Korean immigrants came from a business class.

There are important weaknesses to this cultural explanation. The capital market argument does not seem likely to be crucial to small business. As we saw in SIPP and CBO data, large amounts of capital generally are not need, and new businessman do not regularly borrow. Rotating credit

\footnotetext{
${ }^{32}$ See Light (1972), pp. 15-18.

${ }^{33}$ See Light $(1972,1979,1984)$, Light and Bonacich (1988).
} 
associations tend to provide very short term loans, usually only lasting several months. Even Light's own recent data on Los Angeles Koreans indicates that the vast majority of businesses are selffinanced and do not rely on rotating credit associations. ${ }^{34}$ The other aspects of the cultural explanation merit further study.

\section{Conclusions}

The evidence here does not support the liquidity constraints/low assets explanation for the low black self-employment rate. Black white differences in net worth can only explain a small part of the differences in their rates of business formation. Logit equations for who is self-employed in a cross-section and who becomes self-employed in a panel suggest that net worth is not an important determinant of the racial differences in self-employment. Little capital is needed to start most business and beginning entrepreneurs do not usually borrow. Asso, the industrial distribution of black and white businesses does not indicate a greater relative representation of blacks in industries requiring less starting capital.

This evidence should not be taken to imply that liquidity constraints are unimportant in the establishment of large businesses. I have only examined their importance for the small businesses that the vast majority of entrepreneurs own. However, entrepreneurs commonly begin with a small business, build it up and sell it, and then enter a more capital intensive business. ${ }^{35}$ The rate of very small business formation may be the key indicator of future business success.

I have also examined if black businesses are relatively more common in industries where white customers more frequently patronize black businesses. The evidence does not support this form of

\footnotetext{
${ }^{34}$ See Light and Bonacich (1984), pp. 254-259.

${ }^{35}$ See Light and Bonacich (1988), p. 243 who note this for Korean businesses in Los Angeles.
} 
consumer discrimination, but the conclusion is less definite. I conclude that cultural differences may explain black white differences in self-employment, but this explanation needs further study. 


\section{References}

Ando, Faith (1988): "Capital Issues and the Minority-Owned Business," The Review of Black Political Economy, pp.77-109.

Bates, Timothy (1985a): "Entrepreneur Human Capital Endowments and Minority Business Viability," The Journal of Human Resources, 20, pp. 540-554.

Bates. Timothy (1985b): "Impact of Preferential Procurement Policies on Minority-Owned Business," The Review of Black Political Economy, pp. 51-65.

Bates, Timothy (1989): "The Changing Nature of Minority Business: A Comparative Analysis of Asian, Nonminority, and Black-Owned Businesses." The Review of Black Political Economy, pp. $25 \cdot 42$.

Becker, Gary S. (1971): The Economics of Discrimination, Second Edition, Chicago: University of Chicago Press.

Blanchflower. David G., and Andrew J. Oswald (1990): "What Makes An Entrepreneur," Working Paper, Dartmouth College.

Blau, Francine, and David Graham (1990): "Black-White Differences in Wealth and Asset Composition." Quarterly Journal of Economics, pp. 321-339.

Borjas, George (1986): "The Self-Employment Experience of Immigrants," Journal of Human Resources, 21, pp. 487-506.

Borjas, George and Stephen Bronars (1989): "Consumer Discrimination and Self-employment," Journal of Political Economy, 97, pp. 581-605.

Brown, Charles, James Hamilton and James Medoff (1990): Employers Large and Small, Cambridge: Harvard University Press.

Cain, Glen G. (1986): "The Economic Analysis of Labor Market Discrimination: A Survey," in Handbook of Labor Economics, ed. by Orley Ashenfelter and Richard Layard, Amsterdam: North-Holland.

Chen, Gavin M. and John A. Cole (1988): The Myths, Facts, and Theories of Ethnic, SmallScale Enterprise Financing," The Review of Black Political Economy, pp. 111-123.

Coate, Stephen and Sharon Tennyson (1989): "Labor Market Discrimination, Imperfect Information and Self Employment," Unpublished Paper.

Evans, David and Linda Leighton (1989): "Some Empirical Aspects of Entrepreneurship," American Economic Review, 79, pp. 519-535. 
Evans, David and Boyan Jovanovic (1989); "An Estimated Model of Entrepreneurial Choice Under Liquidity Constraints," Journal of Political Economy, 97. pp. 808-827.

Frazier, E. Franklin (1957): The Negro in the United States, 2nd Edition, New York: McMillan.

Fuchs, Victor R. (1982): "Self-Employment and Labor Force Participation of Older Males," Joumal of Human Resources, 17, pp. 339-357. Glazer, Nathan and Daniel P. Moynihan (1970): Beyond the Melting Pot, 2nd Edition,
Cambridge: MTT Press.

Kinzer, Robert H., and Edward Sagarin (1950): The Negro in American Business, New York:
Greenberg.

Light, Ivan (1972): Ethnic Enterprise in America, Berkeley: University of California Press. Light, Ivan (1979): "Disadvantaged Minorities in Self-Employment," International Journal of
Comparative Sociology, 20, pp. 31-45. Light, Ivan (1984): "Immigrant and Ethnic Enterprise in North America," Ethic and Racial
Studies, 7, pp. 195-216.

Light, Ivan, and Edna Bonacich (1988): Immigrant Entrepreneurs, Berkeley: University of
California Press.

Moore, Robert L. (1983): "Employer Discrimination: Evidence from Self-Employed Workers," Review of Economics and Statistics, 65, pp. 496-501.

Nucci, Al (1989): "The Characteristics of Business Owners (CBO) Database," Center for Economic Studies Discussion Paper CES 89-9, Bureau of the Census.

Rees, H. and A. Shah (1986): "An Empirical Analysis of Self-Employment in the UK," Journal of Applied Econometrics, 1, pp. 95-108.

Sowell, Thomas (1981): Markets and Minorities, New York: Basic Books. Stevens, Richard L. (1984): "Measuring Minority Business Formation and Failure," The Review
of Black Political Economy, pp. 71-84.

U.S. Bureau of the Census (1986): Household Wealth and Asset Ownership: 1984, Current Population Reports, Series P.70, Washington, D.C.: U.S. Government Printing Office. U.S. Bureau of the Census (1987): 1982 Characteristics of Business Owners, Washington, D.C.:
U.S. Government Printing Office.

U.S. Small Business Administration (1988): "Minority Business and Entrepreneurship," in Small Business in the American Economy, Washington, D.C.: U.S. Government Printing Office. 
Table 1

Self-Employwent Rates of Those 16 and Older by Race, Ethricity and Sex t980 Census of Population

\begin{tabular}{|c|c|c|c|c|c|c|}
\hline & Total & White & Black & $\begin{array}{l}\text { Amarican } \\
\text { Indtan }\end{array}$ & Asian & $\begin{array}{l}\text { Spanish } \\
\text { Origin }\end{array}$ \\
\hline \multicolumn{7}{|l|}{ Iotel } \\
\hline Employed & 97639355 & 84027375 & 9334048 & 507614 & 1689070 & 5456857 \\
\hline Total Self-employed & 8747535 & 8229522 & 269015 & $290: 2$ & 244317 & 265845 \\
\hline Enployees of Om Corporation & 2059554 & 1965002 & 45207 & 4771 & 41402 & 59850 \\
\hline Sole Proprietors and Partrera & 5677871 & 6266520 & 223808 & 24241 & 102915 & 205995 \\
\hline Solf-eaployment Rate (t) & 9.0 & 9.8 & 2.9 & 5.7 & B. 5 & 4.9 \\
\hline \multicolumn{7}{|l|}{ Males } \\
\hline Employed & 56004690 & 48843987 & 4674871 & 286687 & 906599 & 3288208 \\
\hline Total Self-employed & 6861020 & 6676605 & 200028 & 21204 & 103461 & 207699 \\
\hline Employens of am Corporation & 1712339 & 1632220 & 34119 & 3603 & 31798 & +7979 \\
\hline Sol. Proprieters and Partiers & 5148681 & 4844385 & 165909 & 17601 & $7: 663$ & 159720 \\
\hline Self-employment Rate ( $t$ ) & 12.3 & 13.3 & 4.3 & 7.4 & 12.4 & 6.3 \\
\hline \multicolumn{7}{|l|}{ Fengles } \\
\hline Employed & 41634665 & 35183388 & 4659177 & 220927 & 782671 & 2168649 \\
\hline Iotal Solf-employod & 1886515 & 1752917 & 68987 & 7808 & 40856 & 58146 \\
\hline Enployees of own Corporation & 357325 & 332782 & 11088 & 1168 & 9604 & 12871 \\
\hline Sole Proprietors and Partners & 1529190 & 1420135 & 57899 & 6640 & 31252 & 46275 \\
\hline Self-amployment Rate (z) & 4.5 & 5.0 & 1.5 & 3.5 & 5.2 & 2. 7 \\
\hline
\end{tabular}

Netes: (t) The self-employment rare is the parcentage of all those working who are selfemployed. (2) In the Census questionnaire. individuals are asked to classify their current job activity as employed by a private company. omployed by the sovermment, self-omployed. or working without pay in fanily business or farm. If a person has more than one job, they are alked to describe the one at which they worked the most hours last week. The self employed are asked to choose between own business not incorparated, and own businoss incorporated. (3) Persons of Sparish origin can be any race. 
Table 2

Self-Employment Rates Calculated from Number of Business Owners, 1982

\begin{tabular}{|c|c|c|c|c|c|}
\hline & Total & $\begin{array}{l}\text { Nonninority } \\
\text { Male }\end{array}$ & $\begin{array}{l}\text { Black } \\
\text { Total }\end{array}$ & $\begin{array}{l}\text { Hispanic } \\
\text { Total }\end{array}$ & Women \\
\hline $\begin{array}{l}\text { Total Non-Agriculcure Employed } \\
\text { Number of Business Owners }\end{array}$ & $\begin{array}{l}97759851 \\
11260739\end{array}$ & $\begin{array}{r}48907892 \\
7582910\end{array}$ & $\begin{array}{r}9284907 \\
325461\end{array}$ & $\begin{array}{r}5622521 \\
262808\end{array}$ & $\begin{array}{r}42736136 \\
3160031\end{array}$ \\
\hline Self-employment Rate ( 8 ) & 11.5 & 15.5 & 3.5 & 4.7 & 7.4 \\
\hline
\end{tabular}

Notes: (1) The self-employment rate is calculated as the number of business owners divided by nonagricultural employment. (2) Number of business otners comes from Nucci (1989), which relies on the 1982 Characteristics of Business Owners.

(3) Total nonagricultural employment is calculated by adding the number of employed Armed Forces from the 1980 Census to the number of employed non-agricultural civilians frow the Handbook of Labor Statistics. 
Table 3

S.lf-Employment Rates of those 16 and Older, by Race. Ethnicity ard Sex 1984 Panel of SIPP, Wave 4

\begin{tabular}{|c|c|c|c|c|c|c|}
\hline & Total & White & Black & Asian & Other & $\begin{array}{l}\text { Hispanze } \\
\text { Origin }\end{array}$ \\
\hline \multicolumn{7}{|l|}{ Iots1 } \\
\hline Enployed & 22,285 & 19,595 & 1.999 & 497 & 34 & 1,062 \\
\hline Self-employed & 2,076 & 1,956 & 59 & 42 & 9 & 70 \\
\hline Employed with side business & 510 & 483 & 13 & 13 & $i$ & 9 \\
\hline Self-employmont rate (I) & $\begin{array}{l}9.4 \\
(0.196)\end{array}$ & $\begin{array}{l}10.0 \\
(0.214)\end{array}$ & $\begin{array}{l}3.5 \\
(0.408)\end{array}$ & $\begin{array}{l}\text { B. } 5 \\
\text { (1. } 248)\end{array}$ & $\begin{array}{c}9.6 \\
(3.035)\end{array}$ & $\begin{array}{c}6.6 \\
(0.761)\end{array}$ \\
\hline $\begin{array}{l}\text { Self-amployment rate including } \\
\text { slde businesses ( }(\mathrm{x})\end{array}$ & $\begin{array}{l}11.7 \\
(0.215)\end{array}$ & $(0.236)$ & $(0.444)$ & $\begin{array}{l}11.1 \\
(1.407)\end{array}$ & $\begin{array}{l}10.6 \\
(3.180)\end{array}$ & $(0.805)$ \\
\hline \multicolumn{7}{|l|}{ Males } \\
\hline Enployed & 22,144 & 10.889 & 924 & 278 & 53 & 620 \\
\hline Self-employed & 1.409 & 1.362 & 40 & 22 & 5 & 53 \\
\hline Employed with side business & 359 & 342 & 8 & 8 & 1 & 4 \\
\hline Self-employment rate (z) & 11.6 & 12.3 & 4.3 & 7.9 & 9.4 & B. 5 \\
\hline & $(0.291)$ & $(0.315)$ & $(0.669)$ & $(1.619)$ & $(4.025)$ & $(1.123)$ \\
\hline Self-erploywent rate ineluding & 14.5 & 15.5 & 5.2 & 10.6 & 11.3 & 9.2 \\
\hline side businesses (z) & $(0.320)$ & $(0,346)$ & $(0.730)$ & $(1.861)$ & $(4,352)$ & $(1.160)$ \\
\hline \multicolumn{7}{|l|}{ Fomales } \\
\hline Employed & 10.041 & 8,706 & 1.075 & 219 & 41 & 442 \\
\hline Self-enployed & 567 & $6: 4$ & 29 & 20 & 4 & 17 \\
\hline Employed with side business & $15:$ & 141 & 5 & $s$ & 0 & 5 \\
\hline Self-employment rate (z) & 6.6 & 7.1 & 2.7 & 9.1 & 9.3 & 3.8 \\
\hline & $(0.249)$ & $(0.274)$ & $(0.494)$ & $(1.947)$ & $(4.534)$ & $(0.915)$ \\
\hline Self-omployment rata inciuding & 8.2 & 8.7 & 3.2 & ii. 4 & 3.5 & 5.0 \\
\hline side businesses ( $(Z)$ & $(0.273)$ & $(0.302)$ & $(0.534)$ & $(2.169)$ & $(4.534)$ & $(1.034)$ \\
\hline
\end{tabular}

Notes: (1) The numbers are sample counts not universe estimates. (2) The sample consists of those who work more than five hours/week. (3) Persons of spanish origin can be any race. (4) Indtviduals are classified as self-employed or employed on the basis of where they worked the most hours. (\$) Those employed with side business afe primazily wage and salary workers. but have some self-empioyment hours. (6) Standard errors aze in parentheses. 
Tato 4

Number and Net Income of Nonminority Male, Black, and Hispanic Owned Buginessen, by I-Digit SIC, I 982 Characteristics of Business Owners Date

\begin{tabular}{|c|c|c|c|c|c|c|c|c|c|c|}
\hline & \multicolumn{5}{|c|}{ Number of Firmg } & \multicolumn{5}{|c|}{ Mean Nat Inecome } \\
\hline & $\begin{array}{l}\text { Whito } \\
\text { Male }\end{array}$ & Black & Elopan!e & $\begin{array}{l}\text { Elacis/ } \\
\text { White } \\
\text { Ratio }\end{array}$ & $\begin{array}{l}\text { Eispanic/ } \\
\text { White } \\
\text { Ratio }\end{array}$ & $\begin{array}{l}\text { White } \\
\text { Male }\end{array}$ & Black & Hispanic & $\begin{array}{l}\text { Black/ } \\
\text { White } \\
\text { Ratio }\end{array}$ & $\begin{array}{c}\text { Hispanic/ } \\
\text { White } \\
\text { Ratio }\end{array}$ \\
\hline & & & & $\cdot$ & & & & & & \\
\hline Agricultur & 264443 & 5105 & 37640 & 0.019 & 0.029 & 26509 & 7708 & 11540 & 0.291 & 0.435 \\
\hline Construction & 943162 & 23061 & 126699 & 0.024 & 0.028 & 15980 & 13759 & $9 \quad 15993$ & 0.861 & 1.001 \\
\hline Manufacturing & 174815 & 4171 & 14364 & 0.024 & 0.025 & 21736 & 3428 & 22239 & 0.158 & 1.023 \\
\hline Traniportation & 290338 & 24397 & 713255 & 0.084 & 0.045 & 15372 & 11215 & 512888 & 0.730 & 0.838 \\
\hline Wholosal. Trade & 143174 & 3631 & 3623 & 0.026 & 0.025 & 36469 & 6680 & 16975 & 0.183 & 0.465 \\
\hline Rarail Irado & 1363666 & 84053 & 358274 & 0.062 & 0.043 & 15519 & 4772 & 212916 & 0.308 & 0.032 \\
\hline Finance & 497143 & 14829 & $9 \quad 11123$ & 0.030 & 0.022 & 32486 & 9947 & 19569 & 0.306 & 0.602 \\
\hline Services & 2548094 & 147263 & 398279 & 0.058 & 0.039 & 26100 & 8539 & 15972 & 0.326 & 0.610 \\
\hline Not Classiflod & 531830 & 32709 & 24983 & 0.052 & 0.040 & 19370 & 8280 & 11186 & 0.427 & 0.578 \\
\hline Total & 5856665 & 339239 & 248141 & 0.049 & 0.036 & 22437 & 7923 & $3 \quad 16781$ & 0.353 & 0.659 \\
\hline
\end{tabular}

Notes: (1) The net income numbers are based on categorical responses to the queation "What was your firm's $1982 \mathrm{nut}$ incore (or loss) before Iares? Net Incone (or loss) 1 s equel to total infowe loss operating expenses." An approximation to the wo an was celculated using the midpoint of each interval and 1.5 times the lower (upper) limit for the category unbounded abovo (bolow). (2) Pursons classified as Hispanic can be of any race. 
Table 5

Earnings of Full-time, Nonagricultural, Self-Employed and Wage and Salary Workers, 16 and Over, by Race, Ethnicity and Sex, 1984 Panel of SIPP, Wave 4

\begin{tabular}{|c|c|c|c|}
\hline & White & Black & $\begin{array}{l}\text { Spanish } \\
\text { Origin }\end{array}$ \\
\hline \multicolumn{4}{|l|}{ Males } \\
\hline \multicolumn{4}{|l|}{ Wage and Salary } \\
\hline Mean Earnings ( $\$$ ) & $\begin{array}{c}22,862 \\
(157.17)\end{array}$ & $\begin{array}{c}16.564 \\
(336.02)\end{array}$ & $\begin{array}{c}16,380 \\
(400.75)\end{array}$ \\
\hline Mean In(Earnings) (\$) & $\begin{array}{c}9.8172 \\
(0.0085)\end{array}$ & $\begin{array}{c}9.5232 \\
(0.0270)\end{array}$ & $\begin{array}{c}9.5354 \\
(0.0286)\end{array}$ \\
\hline Median Earnings $(\$)$ & 20,493 & 15,120 & 14.364 \\
\hline Sample Size & 8,540 & 759 & 511 \\
\hline \multicolumn{4}{|l|}{ Self-employed } \\
\hline Mean Earnings $(\$)$ & $\begin{array}{c}27.928 \\
(833.70)\end{array}$ & $\begin{array}{c}20.183 \\
(3,639.97)\end{array}$ & $\begin{array}{c}25,577 \\
(4,423.65)\end{array}$ \\
\hline Mean Ln(Earnings) ( $\$$ ) & $\begin{array}{c}8.9963 \\
(0.0823)\end{array}$ & $\begin{array}{c}8.8349 \\
(0.4785)\end{array}$ & $\begin{array}{c}9.0345 \\
(0.3511)\end{array}$ \\
\hline Median Earnings $(\$)$ & 18,000 & 13,932 & 15,000 \\
\hline Sample Size & 1,166 & 30 & 49 \\
\hline \multicolumn{4}{|l|}{ Females } \\
\hline \multicolumn{4}{|l|}{ Wage and Salary } \\
\hline Mean Earnings ( $\$$ ) & $\begin{array}{c}13,873 \\
(109.07)\end{array}$ & $\begin{array}{c}12,693 \\
(253.13)\end{array}$ & $\begin{array}{c}11,851 \\
(386.11)\end{array}$ \\
\hline Mean Ln(Earnings) $(\$)$ & $\begin{array}{c}9.3070 \\
(0.0121)\end{array}$ & $\begin{array}{c}9.2256 \\
(0.0315)\end{array}$ & $\begin{array}{c}9.1555 \\
(0.0460)\end{array}$ \\
\hline Median Earnings (\$) & 12.600 & 11,760 & 11,153 \\
\hline Sample Size & 5.640 & 781 & 308 \\
\hline \multicolumn{4}{|l|}{ Self-employed } \\
\hline Mean Earnings ( $(\$)$ & $\begin{array}{c}9,909 \\
(837.29)\end{array}$ & $\begin{array}{c}5,719 \\
(1,026,70)\end{array}$ & $\begin{array}{c}11,015 \\
(4,929.54)\end{array}$ \\
\hline Mean Ln(Earnings) (\$) & $\begin{array}{c}7.0009 \\
(0.1815)\end{array}$ & $\begin{array}{c}7.6421 \\
(0.5180)\end{array}$ & $\begin{array}{c}7.5722 \\
(0.8751)\end{array}$ \\
\hline Median Earnings $(\$)$ & 4,662 & 3,675 & 5.940 \\
\hline Sample Size & 344 & 23 & 12 \\
\hline
\end{tabular}

Notes: (1) Full-time is define as at least 35 hours/week on all jobs. (2) Selfemployment income is from the question "What was the total amount of income that - received from this business (Read each month)?" 
Table 6

Earnings Equations for Wage and Salary and Self-Employed Nonagricultural workers 16 and Older, 1984 SIPP Panel, Wave 4

\begin{tabular}{|c|c|c|c|}
\hline \multirow{2}{*}{ Variable } & \multicolumn{3}{|c|}{ Specification } \\
\hline & (1) & (2) & (3) \\
\hline Sample & All & Wage and Salary & Self-Employed \\
\hline Years of Education & $\begin{array}{l}.0788 \\
(.0031)\end{array}$ & $\begin{array}{l}.0673 \\
(.0022)\end{array}$ & $\begin{array}{l}.1491 \\
(.0229)\end{array}$ \\
\hline Age in Years & $\begin{array}{l}.1006 \\
(.0045)\end{array}$ & $\begin{array}{l}.1015 \\
(.0033)\end{array}$ & $\begin{array}{c}.0512 \\
(.0376)\end{array}$ \\
\hline Age Squared/100 & $\begin{array}{l}-.1147 \\
(.0054)\end{array}$ & $\begin{array}{l}-.1147 \\
(.0040)\end{array}$ & $\begin{array}{l}-.0730 \\
(.0404)\end{array}$ \\
\hline Self-Employed & $\begin{array}{r}-1.2458 \\
(.0313)\end{array}$ & & \\
\hline Male & $\begin{array}{l}.5606 \\
(.0175)\end{array}$ & $\begin{array}{l}.4647 \\
(.0122)\end{array}$ & $\begin{array}{l}1.7939 \\
(.1680)\end{array}$ \\
\hline Black & $\begin{array}{l}-.1356 \\
(.0305)\end{array}$ & $\begin{array}{l}-.1462 \\
(.0204)\end{array}$ & $\begin{array}{c}.3156 \\
(.3925)\end{array}$ \\
\hline Hispanic & $\begin{array}{l}-.0759 \\
(.0413)\end{array}$ & $\begin{array}{l}-.0842 \\
(.0277)\end{array}$ & $\begin{array}{c}.4359 \\
(.3741)\end{array}$ \\
\hline Other Race & $\begin{array}{l}-.1645 \\
(.0543)\end{array}$ & $\begin{array}{l}-.1527 \\
(.0363)\end{array}$ & $\begin{array}{c}.0518 \\
(.4498)\end{array}$ \\
\hline Black»Self-Employed & $\begin{array}{l}.1870 \\
(.1582)\end{array}$ & & \\
\hline Hispanic $\star S e l f-E m p l o y e d$ & $\begin{array}{l}.5183 \\
(.1506)\end{array}$ & & \\
\hline Other Race*Self Employed & $\begin{array}{l}.1689 \\
(.1858)\end{array}$ & & \\
\hline $\begin{array}{l}\text { Married with } \\
\text { Spouse Present }\end{array}$ & $\begin{array}{l}.2334 \\
(.0262)\end{array}$ & $\begin{array}{l}.2377 \\
(.0180)\end{array}$ & $(.2843)$ \\
\hline $\begin{array}{l}\text { Previously Married, or } \\
\text { Spouse Not Present }\end{array}$ & $\begin{array}{l}.1812 \\
(.0326)\end{array}$ & $\begin{array}{l}.1414 \\
(.0225)\end{array}$ & $\begin{array}{l}.6130 \\
(.3571)\end{array}$ \\
\hline
\end{tabular}


Table 6 (continued)

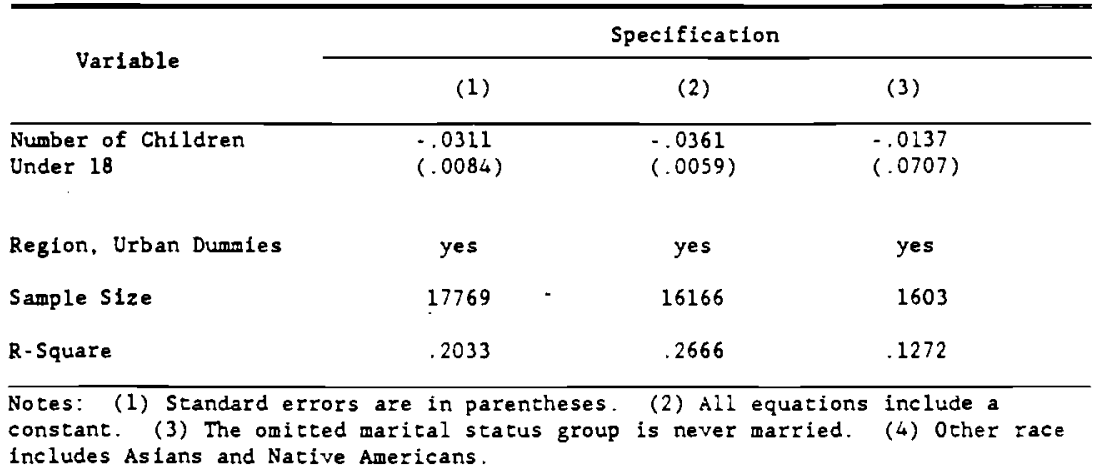


Table 7

Receipts, Number of Employees, and Legal Form of Organization Nonminority Male, Black, and Hispanic Owned Businesses

\begin{tabular}{|c|c|c|c|}
\hline & Nonminortty Male & Black & Hispanic \\
\hline Number of Firms & $6,856,665$ & 339,239 & 248,141 \\
\hline Total Receipts $(\$ 1000)$ & $599,841,888$ & $12,443,572$ & $14,976,337$ \\
\hline Mean Receipts (\$) & 87.483 & 36.681 & 60,354 \\
\hline $\begin{array}{l}\text { Number of Firms with Paid Employees } \\
\text { Percentage of Firms }\end{array}$ & $\begin{array}{r}1,288,869 \\
18.80\end{array}$ & $\begin{array}{r}38,631 \\
11.39\end{array}$ & $\begin{array}{r}39.917 \\
16.09\end{array}$ \\
\hline $\begin{array}{l}\text { Mean Number of Employees } \\
\text { Mean Number of Employees of } \\
\text { Firms with Employees }\end{array}$ & $\begin{array}{l}1.03 \\
5.46\end{array}$ & $\begin{array}{l}0.53 \\
4.63\end{array}$ & $\begin{array}{l}0.85 \\
5.28\end{array}$ \\
\hline Legal Form of organization & & & \\
\hline $\begin{array}{l}\text { Sole Proprietorships } \\
\text { Percentage of Firms }\end{array}$ & $\begin{array}{r}6,276,088 \\
91.53\end{array}$ & $\begin{array}{r}322,975 \\
\quad 95.21\end{array}$ & $\begin{array}{r}233,476 \\
94.09\end{array}$ \\
\hline $\begin{array}{l}\text { Partnerships } \\
\text { Percentage of Firms }\end{array}$ & $\begin{array}{r}341,555 \\
4.98\end{array}$ & $\begin{array}{r}10.166 \\
3.00\end{array}$ & $\begin{array}{r}9.418 \\
3.80\end{array}$ \\
\hline $\begin{array}{l}\text { Corporations } \\
\text { Percentage of Firms }\end{array}$ & $\begin{array}{r}239.022 \\
3.49\end{array}$ & $\begin{array}{r}6,098 \\
1.80\end{array}$ & $\begin{array}{r}5,247 \\
2.11\end{array}$ \\
\hline
\end{tabular}

Notes: (1) Receipts, number of employees, and form of organization come from the categorical responses to the $\mathrm{SMOBE} / \mathrm{WOB}$ Survey reported in the CBO. Approximate means were calculated for receipts and number of employees using the midpoint of the intervals, and 1.5 times the lower limit for the category unbounded from above 
Tablea

Logit Equations for Solf Employment, Honagricuitural Workers 16 and Older, $19 \mathrm{~d}$ ' Panel of SIPP, Have

\begin{tabular}{|c|c|c|c|c|c|c|}
\hline \multirow{2}{*}{ Variable } & \multicolumn{6}{|c|}{ Specification } \\
\hline & (1) & (2) & (3) & $(4)$ & (S) & (6) \\
\hline Saruple & $\mathbf{A} 11$ & $A 11$ & $A I I$ & $A \perp I$ & Whyto & BIack \\
\hline Years of Education & $\begin{array}{c}0.062530 \\
(0.008331)\end{array}$ & $\begin{array}{c}0.035481 \\
(0.008567)\end{array}$ & $\begin{array}{c}0.054386 \\
(0.008469)\end{array}$ & $\begin{array}{c}0.052446 \\
(0.008418)\end{array}$ & $\begin{array}{c}0.055345 \\
(0.008757)\end{array}$ & $\begin{array}{c}0.000356 \\
(0.043256)\end{array}$ \\
\hline Age in Years & $\begin{array}{c}0.080608 \\
(0.011995)\end{array}$ & $\begin{array}{c}0.075832 \\
(0.012228)\end{array}$ & $\begin{array}{c}0.079307 \\
(0.012071)\end{array}$ & $\begin{array}{l}0.084665 \\
(0.012109)\end{array}$ & $\begin{array}{c}0.082999 \\
(0.012445)\end{array}$ & $\begin{array}{c}0.127046 \\
(0.073868)\end{array}$ \\
\hline Age Squared/ 100 & $\begin{array}{l}-0.045807 \\
(0.013120)\end{array}$ & $\begin{array}{l}-0.049280 \\
(0.013406)\end{array}$ & $\begin{array}{l}-0.047455 \\
(0.013214)\end{array}$ & $\begin{array}{l}-0.052625 \\
(0.013271)\end{array}$ & $\begin{array}{l}-0.059370 \\
(0.013619)\end{array}$ & $\begin{array}{l}-0.093544 \\
(0.076842)\end{array}$ \\
\hline Malo & $\begin{array}{c}0.515403 \\
(0.051153)\end{array}$ & $\begin{array}{c}0.524122 \\
(0.051685)\end{array}$ & $\begin{array}{c}0.518407 \\
(0.051304)\end{array}$ & $\begin{array}{c}0.517132 \\
(0.051353)\end{array}$ & $\begin{array}{c}0.536378 \\
(0.053290)\end{array}$ & $\begin{array}{c}0.464222 \\
(0.26264 \div)\end{array}$ \\
\hline Black & $\begin{array}{l}-0.945755 \\
(0.127507)\end{array}$ & $\begin{array}{l}-0.917070 \\
(0.127988)\end{array}$ & $\begin{array}{l}-0.906530 \\
(0.227700)\end{array}$ & $\begin{array}{l}-0.925328 \\
(0.227747)\end{array}$ & & \\
\hline Blspantc & $\begin{array}{l}-0.285523 \\
(0.131810)\end{array}$ & $\begin{array}{l}-0.249764 \\
(0.132531)\end{array}$ & $\begin{array}{l}-0.268038 \\
(0.131853)\end{array}$ & $\begin{array}{l}-0.294318 \\
(0.132153)\end{array}$ & $\begin{array}{l}-0.309532 \\
(0.136536)\end{array}$ & $\begin{array}{l}-0.965812 \\
(1.035451)\end{array}$ \\
\hline Other Race & $\begin{array}{l}-0.198723 \\
(0.153933)\end{array}$ & $\begin{array}{l}-0.157975 \\
(0.154935)\end{array}$ & $\begin{array}{l}-0.186129 \\
(0.154030)\end{array}$ & $\begin{array}{l}-0.219868 \\
(0.154371)\end{array}$ & & \\
\hline $\begin{array}{l}\text { Married with } \\
\text { Spouse Present }\end{array}$ & $\begin{array}{c}0.572958 \\
(0.097922)\end{array}$ & $\begin{array}{c}0.655352 \\
(0.101483)\end{array}$ & $\begin{array}{c}0.599531 \\
(0.099093)\end{array}$ & $\begin{array}{c}0.598844 \\
(0.098741)\end{array}$ & $\begin{array}{c}0.584888 \\
(0.102726)\end{array}$ & $\begin{array}{c}0.749039 \\
(0.519498)\end{array}$ \\
\hline $\begin{array}{l}\text { Proviously Married, or } \\
\text { Spouse Not Present }\end{array}$ & $\begin{array}{c}0.326850 \\
(0.115158)\end{array}$ & $\begin{array}{l}0.515975 \\
(0.118575)\end{array}$ & $\begin{array}{l}0.394994 \\
(0.116475)\end{array}$ & $\begin{array}{c}0.388008 \\
(0.116032)\end{array}$ & $\begin{array}{c}0.368733 \\
(0.221390)\end{array}$ & $\begin{array}{c}0.754528 \\
(0.567037)\end{array}$ \\
\hline $\begin{array}{l}\text { Number of Children } \\
\text { Under } 18\end{array}$ & $\begin{array}{c}0.115982 \\
(0.023282)\end{array}$ & $\begin{array}{c}0.124482 \\
(0.023297)\end{array}$ & $\begin{array}{c}0.120444 \\
(0.023183)\end{array}$ & $\begin{array}{c}0.128222 \\
(0.023183)\end{array}$ & $\begin{array}{c}0.138401 \\
(0.024193)\end{array}$ & $\begin{array}{l}0.155886 \\
(0.114995)\end{array}$ \\
\hline $\begin{array}{l}\text { Net Worth (S100,000's) } \\
\text { (With Business Equity) }\end{array}$ & & $\begin{array}{c}0.243395 \\
(0.017039)\end{array}$ & & & & \\
\hline $\begin{array}{l}\text { Het Worth (\$100,000's) } \\
\text { (Minus Business Equity) }\end{array}$ & & & $\begin{array}{c}0.087073 \\
(0.013620)\end{array}$ & $\begin{array}{l}-0.552776 \\
(0.095709)\end{array}$ & $\begin{array}{l}-0.594824 \\
(0.097880)\end{array}$ & $\begin{array}{c}0.740272 \\
(0.572737)\end{array}$ \\
\hline $\begin{array}{l}\text { Net Wortht } \\
\text { Top Hot Worth Quartile }\end{array}$ & & & & $\begin{array}{c}0.525046 \\
(0.093105)\end{array}$ & $\begin{array}{l}0.655110 \\
(0.095422)\end{array}$ & $\begin{array}{l}0.005234 \\
(0.524447)\end{array}$ \\
\hline $\begin{array}{l}\text { Sum of Coeffictents on } \\
\text { Provtous Iwo Variables }\end{array}$ & & & & $\begin{array}{c}0.073270 \\
(0.013579)\end{array}$ & $\begin{array}{l}0.070286 \\
(0.013338)\end{array}$ & $\begin{array}{c}0.746506 \\
(0.234295)\end{array}$ \\
\hline $\begin{array}{l}\text { Regton and veban } \\
\text { Indicators }\end{array}$ & Yes & Yes & $Y=s$ & Yos & Yes & Yes \\
\hline
\end{tabular}


Table a (continued)

\begin{tabular}{|c|c|c|c|c|c|c|}
\hline \multirow{2}{*}{ Variable } & \multicolumn{6}{|c|}{ Spacification } \\
\hline & (1) & (2) & (3) & $(4)$ & $(5)$ & (6) \\
\hline Actual Black SE Rate & $\begin{array}{c}0.034517 \\
(0.004094)\end{array}$ & $\begin{array}{c}0.034517 \\
(0.004086)\end{array}$ & $\begin{array}{c}0.034517 \\
(0.004084)\end{array}$ & $\begin{array}{c}0.034517 \\
(0.004084)\end{array}$ & & \\
\hline $\begin{array}{l}\text { Predicted Black SE } \\
\text { Rate using White } \\
\text { Equation and Black } \\
\text { Characteristits }\end{array}$ & 0.082111 & 0.073623 & 0.079482 & 0.080947 & & \\
\hline Aetual White SE Rate & $\begin{array}{c}0.099821 \\
(0.002142)\end{array}$ & $\begin{array}{c}0.099821 \\
(0.002142)\end{array}$ & $\begin{array}{c}0.099821 \\
(0.002142)\end{array}$ & $\begin{array}{c}0.099821 \\
(0.002142)\end{array}$ & & \\
\hline $\begin{array}{l}\text { Prodicted white SE } \\
\text { Rate using Bleck } \\
\text { Equation and white } \\
\text { Cheracterigtics }\end{array}$ & 0.044718 & 0.078395 & 0.069367 & 0.069388 & & \\
\hline Sample Size & 22185 & 22185 & 22185 & 22185 & 19595 & 1999 \\
\hline
\end{tabular}

Notes: (1) A 1 is self-employed. (2) standard errors are in parentheses. (3) AlI

equations include a constant. (4) The omitted narital status group 1s never narried. (5)

Other race includes Asians and Native Americans. (6) AIl not worth veriables are in

$\$ 100,000 ' 3$, and exciude business equity uniess otherwise noted. 
Table 9

Logit Equationg for Iransitions to Self Employment, fonegricultural Workers is and Older, 1884 Panel of SIPP

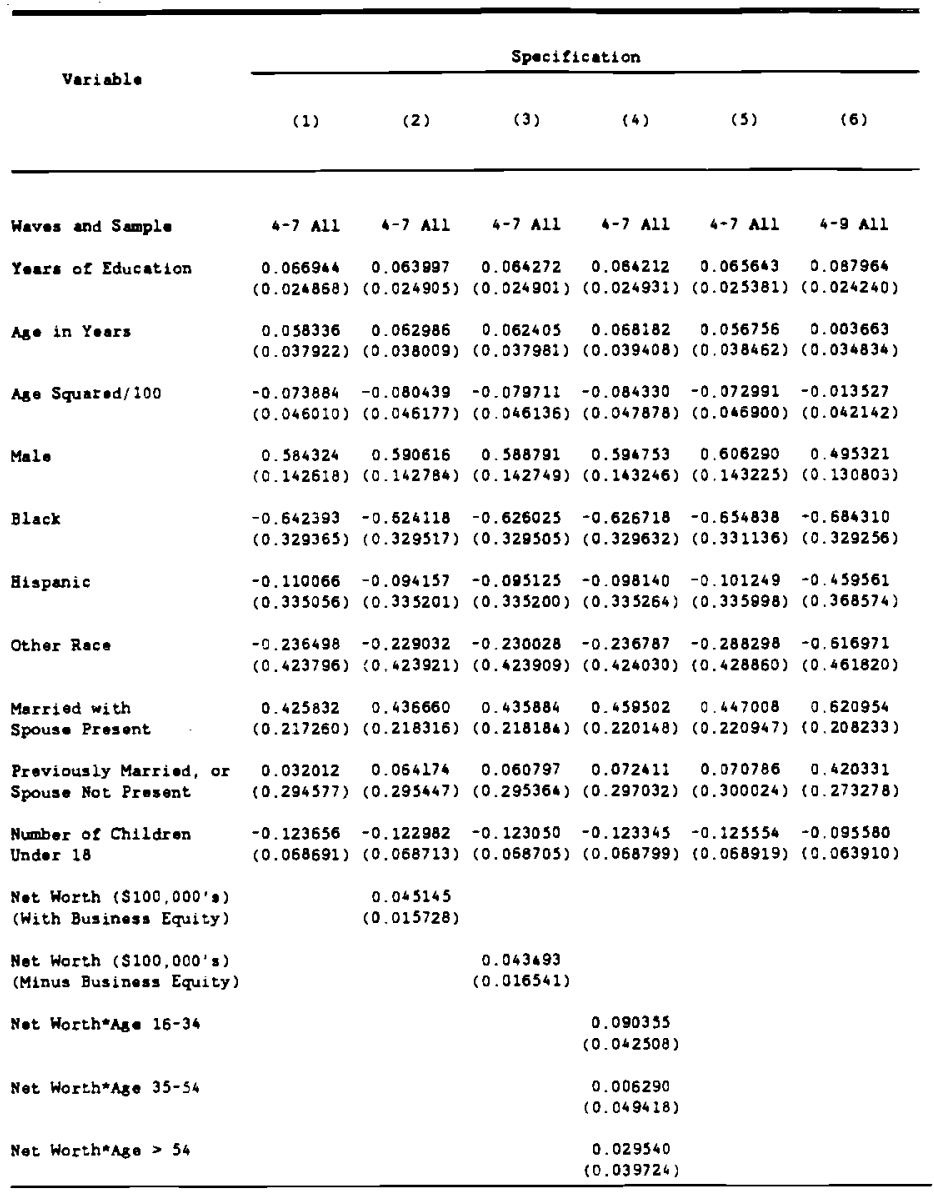


Iabl. 9 (continued)

\begin{tabular}{|c|c|c|c|c|c|c|}
\hline \multirow{2}{*}{ Variable } & \multicolumn{6}{|c|}{ Specification } \\
\hline & $(1)$ & (2) & (3) & (4) & (s) & (6) \\
\hline Real Estat. Net Equity & & & & & $\begin{array}{c}0.231879 \\
(0.105589)\end{array}$ & $\begin{array}{c}0.220098 \\
(0.096799)\end{array}$ \\
\hline Vehiciod Net Equity & & & & & $\begin{array}{l}-1.879673 \\
(1.472950)\end{array}$ & $\begin{array}{l}-1.083754 \\
(1.300259)\end{array}$ \\
\hline Net Liquid Assets & & & & & $\begin{array}{l}-0.507592 \\
(0.250710)\end{array}$ & $\begin{array}{l}-0.036732 \\
(0.125269)\end{array}$ \\
\hline $\begin{array}{l}\text { Equity in IRA's and } \\
\text { X®osh' }\end{array}$ & & & & & $\begin{array}{l}1.114109 \\
(1.018757)\end{array}$ & $\begin{array}{l}1.347821 \\
(0.824655)\end{array}$ \\
\hline Other Asset.s & & & & & $\begin{array}{c}0.050077 \\
(0.019584)\end{array}$ & $\begin{array}{c}0.047408 \\
(0.019174)\end{array}$ \\
\hline $\begin{array}{l}\text { Region \& Urban } \\
\text { Indicators }\end{array}$ & Yes & Yes & Yos & Yes & Yes & Yes \\
\hline $\begin{array}{l}\text { Prodictod Black } \\
\text { SE Rate using White } \\
\text { Equation and Black } \\
\text { Cheracteristics }\end{array}$ & 0.015255 & 0.014981 & 0.015009 & 0.015013 & 0.015368 & 0.017744 \\
\hline Actual Black SE & 0.008306 & 0.008306 & 0.008305 & 0.008305 & 0.008305 & 0.009149 \\
\hline Rate & $(0.002617)$ & $(0.002517)$ & $(0.002617)$ & $(0.002517)$ & $(0.002517)$ & $(0.002881)$ \\
\hline Saple Size & 13296 & 13296 & 13296 & 13296 & 13296 & 12715 \\
\hline
\end{tabular}

Notes: (1) A Z is self-employed. (2) Standard errors are in parentheses. (3) All

equations include a constant. (4) The omitted marital status group is never married. (5) Other Race includes Asians and Native Amertcans. (6) The not worth variables are in

$\$ 100,000^{\prime}$ s and exclude business equity unless otherwise noted. (7) The white transition rate (standard orror) for Have 4 to 7 is $.0192(.0012)$ and for Wave 4 to 9 is 0234

$(.0014)$. 

Nonagricultura: Workers, 16 and Older

\begin{tabular}{|c|c|c|c|c|c|c|}
\hline \multirow{2}{*}{ Variable } & \multicolumn{6}{|c|}{ Specifleation } \\
\hline & $(2)$ & (2) & (3) & $(\omega)$ & (5) & (6) \\
\hline Waves and Sample & $4-7 \quad A 11$ & $4-9 A 11$ & a-7 Wh1te & $4+7 \mathrm{All}$ & $4-7 A 11$ & $6-7 A 11$ \\
\hline Years of Eduction & $\begin{array}{c}0.062618 \\
(0.024843)\end{array}$ & $\begin{array}{c}0.092456 \\
(0.023735)\end{array}$ & $\begin{array}{c}0.071031 \\
(0.026042)\end{array}$ & $\begin{array}{c}0.045670 \\
(0.030794)\end{array}$ & $\begin{array}{c}0.080277 \\
(0.025053)\end{array}$ & $\begin{array}{c}0.067309 \\
(0.027748)\end{array}$ \\
\hline Ase in Yoars & $\begin{array}{c}0.067685 \\
(0.038133)\end{array}$ & $\begin{array}{c}0.013230 \\
(0.034454)\end{array}$ & $\begin{array}{c}0.100285 \\
(0.041381)\end{array}$ & $\begin{array}{c}0.087081 \\
(0.038381)\end{array}$ & $\begin{array}{c}0.096427 \\
(0.038702)\end{array}$ & $\begin{array}{c}0.135826 \\
(0.043876)\end{array}$ \\
\hline Age Squared/:00 & $\begin{array}{l}-0.085357 \\
(0.046314)\end{array}$ & $\begin{array}{l}-0.020338 \\
(0.041537)\end{array}$ & $\begin{array}{l}-0.129496 \\
(0.050848)\end{array}$ & $\begin{array}{l}-0.107863 \\
(0.046445)\end{array}$ & $\begin{array}{l}-0.115592 \\
(0.047196)\end{array}$ & $\begin{array}{l}-0.197814 \\
(0.053871)\end{array}$ \\
\hline Male & $\begin{array}{c}0.589048 \\
(0.142765)\end{array}$ & $\begin{array}{c}0.476998 \\
(0.130468)\end{array}$ & $\begin{array}{c}0.627389 \\
(0.149529)\end{array}$ & $\begin{array}{l}0.595017 \\
(0.162545)\end{array}$ & $\begin{array}{c}0.720279 \\
(0.254184)\end{array}$ & $\begin{array}{c}0.902622 \\
(0.173961)\end{array}$ \\
\hline B lack & $\begin{array}{l}-0.644251 \\
(0.329788)\end{array}$ & $\begin{array}{l}-0.731223 \\
(0.328: 93)\end{array}$ & & $\begin{array}{l}-0.381157 \\
(0.333254)\end{array}$ & $\begin{array}{l}-0.649748 \\
(0.331175)\end{array}$ & $\begin{array}{l}-0.838291 \\
(0.623175)\end{array}$ \\
\hline Hispan1c & $\begin{array}{l}-0.103575 \\
(0.335496)\end{array}$ & $\begin{array}{l}-0.489363 \\
(0.368148)\end{array}$ & $\begin{array}{l}-0.140715 \\
(0.353613)\end{array}$ & $\begin{array}{l}-0.074490 \\
(0.337249)\end{array}$ & $\begin{array}{l}-0.084540 \\
(0.338190)\end{array}$ & $\begin{array}{l}-0.006943 \\
(0.357416)\end{array}$ \\
\hline Other Race & $\begin{array}{c}-0.253551 \\
(0.424211)\end{array}$ & $\begin{array}{l}-0.605025 \\
(0.460486)\end{array}$ & & $\begin{array}{l}-0.255283 \\
(0.426555)\end{array}$ & $\begin{array}{l}-0.292275 \\
(0.431456)\end{array}$ & $\begin{array}{l}-0.127993 \\
(0.435961)\end{array}$ \\
\hline $\begin{array}{l}\text { Married with } \\
\text { Spouge Present }\end{array}$ & $\begin{array}{c}0.432299 \\
(0.217430)\end{array}$ & $\begin{array}{c}0.571466 \\
(0.203896)\end{array}$ & $\begin{array}{c}0.440353 \\
(0.225654)\end{array}$ & $\begin{array}{c}0.505210 \\
(0.219800)\end{array}$ & $\begin{array}{c}0.349204 \\
(0.229455)\end{array}$ & $\begin{array}{c}0.662109 \\
(0.235729)\end{array}$ \\
\hline $\begin{array}{l}\text { Proviousiy Married, or } \\
\text { Spouse Not Present }\end{array}$ & $\begin{array}{l}0.048040 \\
(0.294763)\end{array}$ & $\begin{array}{c}0.343043 \\
(0.267260)\end{array}$ & $\begin{array}{l}-0.121786 \\
(0.321541)\end{array}$ & $\begin{array}{l}0.087707 \\
(0.296559)\end{array}$ & $\begin{array}{c}0.115532 \\
(0.295284)\end{array}$ & $\begin{array}{c}0.060088 \\
(0.329567)\end{array}$ \\
\hline $\begin{array}{l}\text { Nurber of Children } \\
\text { Under is. }\end{array}$ & $\begin{array}{l}-0.115545 \\
(0.068800)\end{array}$ & $\begin{array}{l}-0.087970 \\
(0.063803)\end{array}$ & $\begin{array}{l}-0.145673 \\
(0.072509)\end{array}$ & $\begin{array}{l}-0.121215 \\
(0.068190)\end{array}$ & $\begin{array}{l}-0.122995 \\
(0.059117)\end{array}$ & $\begin{array}{l}-0.178842 \\
(0.077853)\end{array}$ \\
\hline $\begin{array}{l}\text { Net Worth (\$100,000's) } \\
\text { (Minus Susiness Equlty) }\end{array}$ & $\begin{array}{l}-0.396792 \\
(0.271959)\end{array}$ & $\begin{array}{l}-0.488526 \\
(0.254948)\end{array}$ & $\begin{array}{l}-0.34181: \\
(0.279078)\end{array}$ & $\begin{array}{l}-0.328443 \\
(0.272403)\end{array}$ & $\begin{array}{l}-0.284401 \\
(0.273892)\end{array}$ & $\begin{array}{c}0.037414 \\
(0.298975)\end{array}$ \\
\hline $\begin{array}{l}\text { Net Worth* } \\
\text { Top Wet Worth Quartile }\end{array}$ & $\begin{array}{l}0.438402 \\
(0.270361)\end{array}$ & $\begin{array}{c}0.533429 \\
(0.253532)\end{array}$ & $\begin{array}{c}0.385799 \\
(0.277497)\end{array}$ & $\begin{array}{c}0.36923: \\
(0.270722)\end{array}$ & $\begin{array}{c}0.335974 \\
(0.272208)\end{array}$ & $\begin{array}{c}0.032290 \\
(0.296788)\end{array}$ \\
\hline $\begin{array}{l}\text { Sum of Coefficients on } \\
\text { Last Iwo Variables }\end{array}$ & $\begin{array}{c}0.061610 \\
(0.016790)\end{array}$ & $\begin{array}{c}0.044903 \\
(0.015320)\end{array}$ & $\begin{array}{c}0.043988 \\
(0.016771)\end{array}$ & $\begin{array}{c}0.040788 \\
(0.027257)\end{array}$ & $\begin{array}{c}0.051573 \\
(0.016923)\end{array}$ & $\begin{array}{c}0.068704 \\
(0.019429)\end{array}$ \\
\hline
\end{tabular}


Tabl. 10 (cont1nued)

\begin{tabular}{|c|c|c|c|c|c|c|}
\hline \multirow{2}{*}{ Varlable } & \multicolumn{6}{|c|}{ Specitication } \\
\hline & (1) & (2) & (3) & (4) & (s) & (6) \\
\hline $\begin{array}{l}\text { Los (eamings), } \\
\text { period } t-1\end{array}$ & & & & & $\begin{array}{l}-0,340448 \\
(0.051181)\end{array}$ & $\begin{array}{l}-0.257288 \\
(0.065765)\end{array}$ \\
\hline $\begin{array}{l}\text { Log }(f \operatorname{am} 1 \text { ly } 1 \mathrm{ne000}) \text {; } \\
\text { period } t-1 \text {, }\end{array}$ & & & & & $\begin{array}{l}-0.042082 \\
(0.093252)\end{array}$ & $\begin{array}{l}-0.084286 \\
(0.106276)\end{array}$ \\
\hline $\begin{array}{l}\text { Log (hours worked), } \\
\text { poriod } t-1\end{array}$ & & & & & $\begin{array}{c}0.762436 \\
(0.197200)\end{array}$ & $\begin{array}{c}0.732174 \\
(0.214079)\end{array}$ \\
\hline $\begin{array}{l}\text { Less than } 25 \text { Employees } \\
\text { at Current Job }\end{array}$ & & & & & & $\begin{array}{c}0.758213 \\
(0.150657)\end{array}$ \\
\hline $\begin{array}{l}\text { Tenure at Current } \\
\text { Job (years) }\end{array}$ & & & & & & $\begin{array}{l}-0.046911 \\
(0.013554)\end{array}$ \\
\hline Union Member & & & & & & $\begin{array}{l}-0.846382 \\
(0.282627)\end{array}$ \\
\hline $\begin{array}{l}\text { Region and Urban } \\
\text { Indicators }\end{array}$ & Yes & Yes & Yea & Yes & Yos & Yon \\
\hline $\begin{array}{l}\text { Industry and } \\
\text { Oecupation Indicators }\end{array}$ & & & & Yes & & \\
\hline $\begin{array}{l}\text { Fredicted Black } \\
\text { SE Rate using white } \\
\text { Equation and glack } \\
\text { Characteristics }\end{array}$ & 0.015250 & 0.018572 & & 0.014362 & 0.015367 & 0.011930 \\
\hline $\begin{array}{l}\text { Actual Black SE } \\
\text { Rat• }\end{array}$ & $\begin{array}{c}0.008306 \\
(0.002617)\end{array}$ & $\begin{array}{l}0.009149 \\
(0.002581)\end{array}$ & & $\begin{array}{c}0.006306 \\
(0.002617)\end{array}$ & $\begin{array}{c}0.008306 \\
(0.002617)\end{array}$ & $(0.005382)$ \\
\hline Samplo Size & 13296 & 12715 & 11749 & 13296 & 23296 & 12671 \\
\hline
\end{tabular}

Notes: (2) See notes to Tab1. 9 . (2) the white solf-employment rate (standard error) for
specification (6) is $.0170(.0012)$ 
Iabl. 11

Logit Equations for Iraneitions out of Self Employment, Nonagricultural Workers, 16 and Older

\begin{tabular}{|c|c|c|c|}
\hline \multirow{2}{*}{ Veriable } & \multicolumn{3}{|c|}{ Specification } \\
\hline & (1) & (2) & (3) \\
\hline Waves and Sample & $4-7-9$ A.1 & $4-7-9 \quad A 11$ & $\begin{array}{l}\text { 4-7-9 Completely } \\
\text { SE or WS }\end{array}$ \\
\hline Years of Education & $\begin{array}{l}-0.0979 \\
(0.0525)\end{array}$ & $\begin{array}{l}-0.1065 \\
(0.0542)\end{array}$ & $\begin{array}{l}-0.1045 \\
(0.0009)\end{array}$ \\
\hline Ase in Years & $\begin{array}{c}0.1265 \\
(0.0976)\end{array}$ & $\begin{array}{c}0.1951 \\
(0.1058)\end{array}$ & $\begin{array}{c}0.1546 \\
(0.1303)\end{array}$ \\
\hline As* Squared $/ 100$ & $\begin{array}{l}-0.1566 \\
(0.1194)\end{array}$ & $\begin{array}{l}-0.2439 \\
(0.1301)\end{array}$ & $\begin{array}{l}-0.1789 \\
(0.1594)\end{array}$ \\
\hline Male & $\begin{array}{c}0.1576 \\
(0.3367)\end{array}$ & $\begin{array}{c}0.4119 \\
(0.3821)\end{array}$ & $\begin{array}{l}-0.3665 \\
(0.4791)\end{array}$ \\
\hline Black & $\begin{array}{c}0.1632 \\
(0.8280)\end{array}$ & $\begin{array}{l}0.0467 \\
(0.0386)\end{array}$ & $\begin{array}{c}0.4398 \\
(0.9337)\end{array}$ \\
\hline Hispanie & $\begin{array}{c}0.4210 \\
(0.7244)\end{array}$ & $\begin{array}{c}0.4679 \\
(0.7345)\end{array}$ & $\begin{array}{l}0.3072 \\
(1.0230)\end{array}$ \\
\hline $\begin{array}{l}\text { Married with } \\
\text { Spouse Prosent }\end{array}$ & $\begin{array}{l}-0.7312 \\
(0.5146)\end{array}$ & $\begin{array}{l}-0.7659 \\
(0.5316)\end{array}$ & $\begin{array}{l}-1.9590 \\
(0.7191)\end{array}$ \\
\hline $\begin{array}{l}\text { Previously Married, or } \\
\text { Spousa Not Present. }\end{array}$ & $\begin{array}{l}-1.7532 \\
(0.8462)\end{array}$ & $\begin{array}{l}-1.4878 \\
(0.8544)\end{array}$ & $\begin{array}{l}-2.6409 \\
(1.0914)\end{array}$ \\
\hline $\begin{array}{l}\text { Nurrber of Children } \\
\text { Under } 19\end{array}$ & $\begin{array}{c}0.0143 \\
(0.1586)\end{array}$ & $\begin{array}{l}-0.0365 \\
(0.1627)\end{array}$ & $\begin{array}{c}0.1014 \\
(0.2295)\end{array}$ \\
\hline $\begin{array}{l}\text { Ret Worth }(\$ 100,000 \text { 's) } \\
\text { (Minus Business Equity) }\end{array}$ & $\begin{array}{l}-0.0370 \\
(0.0710)\end{array}$ & $\begin{array}{l}-0.0545 \\
(0.0907)\end{array}$ & $\begin{array}{l}-0.0482 \\
(0.0761)\end{array}$ \\
\hline $\operatorname{Ln}(i n \operatorname{cose})$ & & $\begin{array}{l}-0.2967 \\
(0.1649)\end{array}$ & \\
\hline $\operatorname{Ln}(\operatorname{lamily}$ incoro) & & $\begin{array}{c}0.3373 \\
(0.2177)\end{array}$ & \\
\hline In (hours on last job) & & $\begin{array}{l}-0.0157 \\
(0.3869\rangle\end{array}$ & \\
\hline Sample Size & 228 & 220 & 153 \\
\hline
\end{tabular}

Hotes: (1) All specifications include a constant, region indicator variables, an urban indicator, and an indicator for other race which includes Asians and lative Americans. (2) Standard ezzors aze in parentheses. (3) The dependent variable -quals one if a person is not longer self-employed, i. - ther not ouployed, or omployed as a wage and salary worker. (4) The sample failure rate (standard error) for colums (1) and (2) is .3070 (.0305) and for colum (3) is .2353 (.0343). 
Table 12

Amount of Startup Capital Needed, and Amount Borrowed, for Nonminoricy Male, Black, and Hispanic owned Businesses 1982 Characteristics of Business Owners,

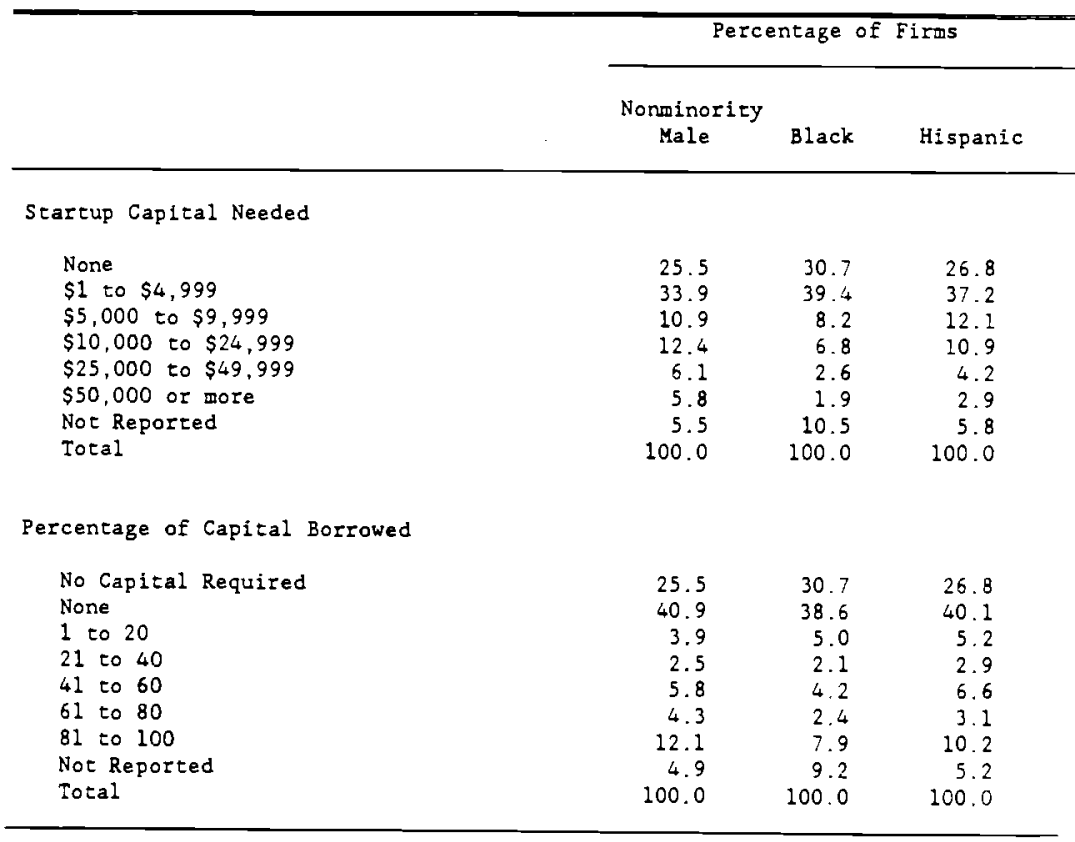

Notes: The startup capital needed comes frow the question reported in the text The percentage of capital borrowed comes from the question "What percent of the capital did you borrow?" which was asked of business owners who responded that they needed at least $\$ 1$ to start their business. 
Table 13

Sources of Borrowed Capital and Sources of Equity Capital, for Nonminority Male, Black, and Hispanic Owned Businesses, 1982 Characteristics of Business Owners

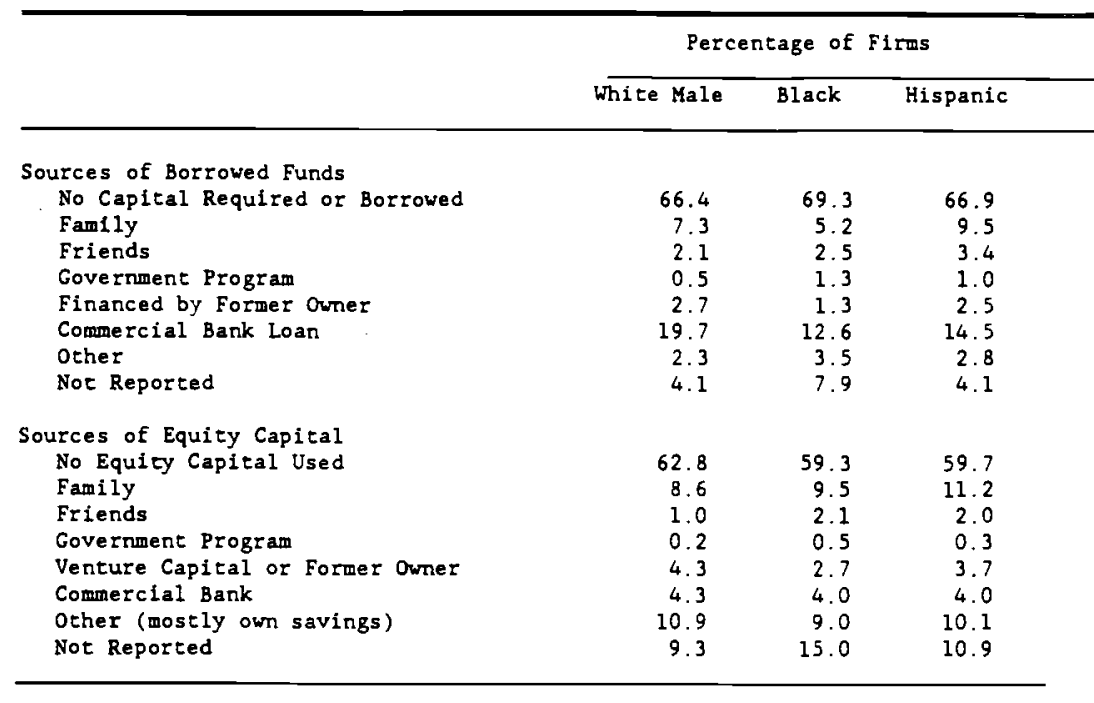

Notes: (1) Numbers may sum to over 100 percent since multiple responses are allowed. (2) Sources of borrowed funds comes from the question "From which of the following sources did you borrow money to become an owner of this business? Mark ( $x$ ) all that apply." Sources of equity capital comes from the question "From which of the following sources did you obtain EQUITY CAPITAL (not borrowed) to become an owner of this business? Mark ( $x$ ) all that apply." 
Tablo 14

Number of Firms. Percentage of Businesses with Primarily Minority Customers, Forcentage with Startup Capital Less than S5,000, for Blacks and Hanoinority Males, 2-Digit Industries, 1982 Characteristics of Businesa Omars

\begin{tabular}{|c|c|c|c|c|c|c|c|c|}
\hline \multirow[b]{2}{*}{$\operatorname{sic}$} & \multirow[b]{2}{*}{ Industry Deacription } & \multicolumn{2}{|c|}{$\begin{array}{l}\text { Nunober of } \\
\text { Businesseas }\end{array}$} & \multirow{2}{*}{$\begin{array}{l}\text { Black/ } \\
\text { White } \\
\text { Ratio }\end{array}$} & \multicolumn{2}{|c|}{$\begin{array}{c}\text { Percent of Firms } \\
\text { with }<5,000 \\
\text { Startup Capital }\end{array}$} & \multicolumn{2}{|c|}{$\begin{array}{l}\text { Percent of Firrs } \\
\text { with Primarily } \\
\text { Minority Custogers }\end{array}$} \\
\hline & & BLack & White & & Black & White & Elack & Whet \\
\hline 0 & Not Classifled & 31034 & 636827 & 0.049 & 02.12 & 67.33 & 74.03 & 27.21 \\
\hline 7 & Abricultural services & $310:$ & 117906 & 0.026 & 80.11 & 63.70 & 44.46 & \\
\hline 8 & Forestry & 571 & 25231 & 0.037 & 57.04 & 58.79 & & 49.33 \\
\hline 9 & Fishing, hunting, and trapping & 754 & 49213 & 0.015 & 61.20 & 51.43 & & \\
\hline 10 & Metal mining & 38 & 1920 & 0.020 & & & & 70.53 \\
\hline 11 & Anthracite mining & & 1495 & 0.000 & & & & \\
\hline 12 & Bituminous coal and lignite mining & & 1587 & 0.000 & & & & \\
\hline 13 & 011 and sas axtraction & 158 & 138827 & 0.001 & & 35.13 & & \\
\hline 14 & Nonmetalic minerals, except fuels & 20 & 4870 & 0.004 & & 50.61 & & \\
\hline 15 & General building contractors & 3475 & 218295 & 0.016 & 84.46 & 65.03 & 61.45 & \\
\hline 16 & Heavy censtruction contractors & 482 & 39821 & 0.012 & 89.01 & 51.48 & & \\
\hline 17 & Special trade contractors & 17744 & 741400 & 0.024 & 87.07 & 01. 51 & 53.31 & 21.50 \\
\hline 20 & Food and kindred products & 29 & 5095 & 0.005 & & 36.81 & & \\
\hline 22 & Ioxt1le mill products & 122 & 2423 & 0.050 & & & & \\
\hline 23 & Apperel and other toxtile products & 248 & 5408 & 0.045 & & 37.48 & & \\
\hline 24 & Lumber and wood products & 1580 & 43926 & 0.036 & 03,60 & 73.92 & & \\
\hline $\begin{array}{l}25 \\
25\end{array}$ & $\begin{array}{l}\text { Furniture and firtures } \\
\text { Paper and allied products }\end{array}$ & 118 & $\begin{array}{l}9326 \\
1876\end{array}$ & $\begin{array}{l}0.013 \\
0.000\end{array}$ & & 65.55 & & \\
\hline 27 & Printing and publishing & 918 & 44613 & 0.021 & 73.19 & 61.60 & 69.71 & \\
\hline 28 & Chemicals and allied products & 70 & 1750 & 0.040 & & 28.50 & & \\
\hline 29 & Potroloun and coal products & & 210 & 0.000 & & & & \\
\hline 30 & Rubber and miscellaneous plastics & & 1261 & 0.000 & & . & & \\
\hline 31 & Leather and leather products & 170 & 936 & 0.102 & & & & \\
\hline 32 & Stene, clay, and glass products & 97 & 12041 & 0.008 & & 71.49 & & \\
\hline 33 & Primary metal industries & 100 & 4854 & 0.021 & & 42.49 & & \\
\hline 34 & Fabricated metal products & 26 & 11757 & 0.002 & & 44.98 & & \\
\hline 35 & Machinezy, except electrical & 61 & 16582 & 0.004 & & 47.39 & & 25.44 \\
\hline 36 & Eloctrical, bectronic equipont & 106 & 5095 & 0.021 & & 63.21 & & \\
\hline 37 & Iransportation equipoent. & 26 & 2373 & 0.011 & & & & \\
\hline 39 & Instruments and related products & & 1077 & 0.000 & & & & \\
\hline 39 & Miscellonøous wanufacturing & 444 & 37283 & 0.012 & 79.04 & 65.68 & & \\
\hline 40 & Ratiroad transportation & & 340 & 0.000 & & & & \\
\hline $4:$ & Local, interurban passenger transit & 7045 & 19667 & 0.358 & 73.74 & 50.50 & 67.35 & \\
\hline 42 & Irucking and warehousing & 12517 & 219627 & 0.057 & 52.46 & 33.22 & 40.50 & 34.49 \\
\hline 44 & Water transportation & 40 & 5312 & 0.008 & & 14.99 & & \\
\hline 45 & Transportation by air & 51 & 7954 & 0.006 & & 34.28 & & \\
\hline
\end{tabular}


Table 14 (continued)

\begin{tabular}{|c|c|c|c|c|c|c|c|c|}
\hline \multirow[b]{2}{*}{ SIC } & \multirow[b]{2}{*}{ Industry Description } & \multicolumn{2}{|c|}{$\begin{array}{l}\text { Number of } \\
\text { Businesses }\end{array}$} & \multirow{2}{*}{$\begin{array}{l}\text { Black } / \\
\text { Whito } \\
\text { Retio }\end{array}$} & \multicolumn{2}{|c|}{$\begin{array}{l}\text { Percent of Firms } \\
\text { with }<\text { SS,000 } \\
\text { Startup Capital }\end{array}$} & \multicolumn{2}{|c|}{$\begin{array}{l}\text { Percent of Firms } \\
\text { with Primarily } \\
\text { Minority Cut toons }\end{array}$} \\
\hline & & Black & White & & Biack & White & Black & White \\
\hline 46 & Pipe lines, except natural gat & & 856 & 0.000 & & & & \\
\hline 47 & Transportation services & 2219 & 26763 & 0.083 & 70.37 & 47.99 & 62.64 & \\
\hline 46 & Conominication & 200 & 9742 & 0.020 & & 38.94 & & \\
\hline 49 & $\begin{array}{l}\text { Eloctric, sas, and enitery eervices } \\
\text { Wholeselo trade-durable soods }\end{array}$ & $\begin{array}{l}1385 \\
1027\end{array}$ & $\begin{array}{l}19405 \\
97958\end{array}$ & $\begin{array}{l}0.071 \\
0.012\end{array}$ & $\begin{array}{l}80.50 \\
70.22\end{array}$ & $\begin{array}{l}63.71 \\
54.04\end{array}$ & & \\
\hline 51 & Who leaklo erade-nondurable sooda & 2247 & 99267 & 0.023 & 80.21 & 61.50 & 78.44 & 20.95 \\
\hline 32 & Bullding meteriels. Berden supplies & 529 & 47254 & 0.011 & 64.36 & 44.52 & & 21.04 \\
\hline 53 & General merchendise stores & 864 & 19586 & 0.043 & 77.05 & 55.19 & & 20.36 \\
\hline 54 & Food etores & 9027 & 125515 & 0.072 & 59.16 & 32.79 & 67.70 & 24.20 \\
\hline $\begin{array}{l}55 \\
58\end{array}$ & $\begin{array}{l}\text { Automotive dealers, envice stations } \\
\text { Apparol and accomory tor tos }\end{array}$ & $\begin{array}{l}3192 \\
2017\end{array}$ & $\begin{array}{r}166029 \\
45856\end{array}$ & $\begin{array}{l}0.019 \\
0.044\end{array}$ & $\begin{array}{l}56.07 \\
74.92\end{array}$ & $\begin{array}{r}39.52 \\
43.21\end{array}$ & $\begin{array}{l}82.22 \\
83.91\end{array}$ & 21.38 \\
\hline 57 & Fumiture, hose fumishings stores & 1919 & 72033 & 0.027 & 77.41 & 57.23 & 69.38 & 19.94 \\
\hline 58 & Eating and drinking places & 12143 & 176917 & 0.069 & 59.93 & 27.39 & 92.95 & 13.24 \\
\hline 59 & Miscellaneous retail & 50015 & 836915 & 0.060 & 94.35 & 69.97 & 85.51 & 25.24 \\
\hline 60 & Banking & 221 & 10155 & 0.022 & & 55.68 & & \\
\hline 61 & Credit agoneies other than barks & 20 & 1175 & 0.017 & & & & 33.18 \\
\hline 62 & Security and comodity brokers & 90 & 12040 & 0.007 & & 45.39 & & \\
\hline 63 & Insurance carriers & & 1842 & 0.000 & & & & \\
\hline 64 & Ineurance agents and brokers & 5289 & 205797 & 0.025 & 90.13 & 81.94 & 88.97 & 15.84 \\
\hline 65 & Real estate & 8583 & 403251 & 0.021 & 78.29 & 53,58 & 84.24 & 24.53 \\
\hline 66 & Coobined real estate, insurance & 144 & 4240 & 0.035 & & 57.02 & & \\
\hline 67 & Bolding and other investont offices & & 4841 & 0.000 & & & & \\
\hline 70 & Eotels and other lodging places & 1123 & 53790 & 0.021 & 54.00 & 20.18 & 81.15 & \\
\hline 72 & Personal services & 39410 & 290226 & 0.135 & 78.58 & 70.41 & 86.85 & 19.85 \\
\hline 73 & Business services & 28897 & 657550 & 0.044 & 85.56 & 68.66 & 57.26 & 23.80 \\
\hline 75 & Auto ropair, services, and sarages & 6902 & 209174 & 0.033 & 77.13 & 57.48 & 73.53 & 24.44 \\
\hline 76 & Miscellaneous repair services & 3693 & 245604 & 0.025 & 77.95 & 76.04 & 68.21 & 22.89 \\
\hline 78 & Motion pictures & 349 & 13256 & 0.026 & & 58.15 & & \\
\hline 79 & Amus ement and recreation services & 7394 & 187012 & 0.040 & 79.02 & 67.55 & 67.45 & 33.17 \\
\hline 80 & Bealth services & 16693 & 262054 & 0.054 & 71.82 & 46.13 & 67.22 & 15.16 \\
\hline 81 & Legal services & 3841 & 195549 & 0.020 & 84.96 & 67.65 & 90.92 & 18.97 \\
\hline 82 & Educational services & 2529 & 67187 & 0.038 & 86.93 & 97.28 & & \\
\hline 83 & Social sciences & 322 & 2409 & 0.134 & & & & \\
\hline 89 & Miscellaneous services & 31744 & 597557 & 0.045 & 83.60 & 71.80 & 69.60 & 23.02 \\
\hline 99 & Total & 324344 & 7584269 & 0.043 & 78.55 & 62.87 & 73.78 & 22.90 \\
\hline
\end{tabular}

Notes (1) These numbers are derived from special eabulations done by the Center for Economic Studies Buresu of the Consus. 
Tabla 15

Regression Equations tor Log of Black/hitite Male Ratto of Nurber of Businesses, By 2-Digit SIC

\begin{tabular}{|c|c|c|c|c|c|c|}
\hline \multirow{2}{*}{ Variable } & \multicolumn{6}{|c|}{ Spocification } \\
\hline & (1) & (2) & (3) & (4) & (5) & (E) \\
\hline \multicolumn{7}{|l|}{ Fuil Sample: } \\
\hline $\begin{array}{l}\text { Fraction of Black Businestea } \\
\text { With < s5000 Slarting Cepital }\end{array}$ & $\begin{array}{l}-0.1329 \\
(0.8414)\end{array}$ & & & & $\begin{array}{l}-0.5392 \\
(0.9241)\end{array}$ & \\
\hline $\begin{array}{l}\text { Fraction of Whit Buaineasas } \\
\text { With }<5000 \text { Starting Capital }\end{array}$ & & $\begin{array}{l}0.6945 \\
(0.6038)\end{array}$ & & & & $\begin{array}{l}-0.2939 \\
(0.4208)\end{array}$ \\
\hline $\begin{array}{l}\text { Fraction of Black Businesses } \\
\text { with = 502 Minority Customers }\end{array}$ & & & $\begin{array}{l}0.0654 \\
(0.6809)\end{array}$ & & $\begin{array}{c}0.0611 \\
(0.6910)\end{array}$ & $\begin{array}{l}-0.0147 \\
(0.6936)\end{array}$ \\
\hline $\begin{array}{l}\text { Eraction of White Busingsses } \\
\text { With }>\text { Soz Minority Customers }\end{array}$ & & & & $\begin{array}{l}-0.2890 \\
(0.4306)\end{array}$ & & \\
\hline Sarplo Sizo & 36 & 51 & 26 & 24 & 26 & 26 \\
\hline \multicolumn{7}{|l|}{ Reduced Sarple: } \\
\hline $\begin{array}{l}\text { Fraction of Black Musinesses } \\
\text { With }<\$ 5000 \text { Starting Capital }\end{array}$ & $\begin{array}{c}0.1848 \\
(0.8317)\end{array}$ & & & & & \\
\hline $\begin{array}{l}\text { Fraction of Whit Businesses } \\
\text { With }<\$ 5000 \text { Starting Capital }\end{array}$ & & $\begin{array}{r}-0.1420 \\
(0.3879)\end{array}$ & & & & \\
\hline \multicolumn{7}{|l|}{ Fraction of Black Bustnesses } \\
\hline $\begin{array}{l}\text { Fraction of White Bustnesses } \\
\text { With > soz Minortty Customers }\end{array}$ & & & & $\begin{array}{c}0.0312 \\
(0.4517)\end{array}$ & & \\
\hline Sarple Size & 34 & 34 & & 22 & & \\
\hline
\end{tabular}

Notes: (I) The dependent variable is the log of the ratio of the number of black owned businessen th the 2-digit sid to the number of white male owned businesses in that industry. All explanatery rariables are in logs. (2) The roduced samplo corsists of only those 2-digit SIC's in which the number of black businesses is at least 500 and the number of thite mele businesses is at least 10,000. (3) The Eu11 samplo and reduced samples aro the same for specifications 3,5 , and $\bar{E}$. (4) All equations include a constant. (5) Standard errors are in parenthesas. 
Figure 1

Black / White Ratio of Number of Businesses, for 1-Digit Industries By Percentage of Black Businesses with $<\$ 5,000$ Startup Capital

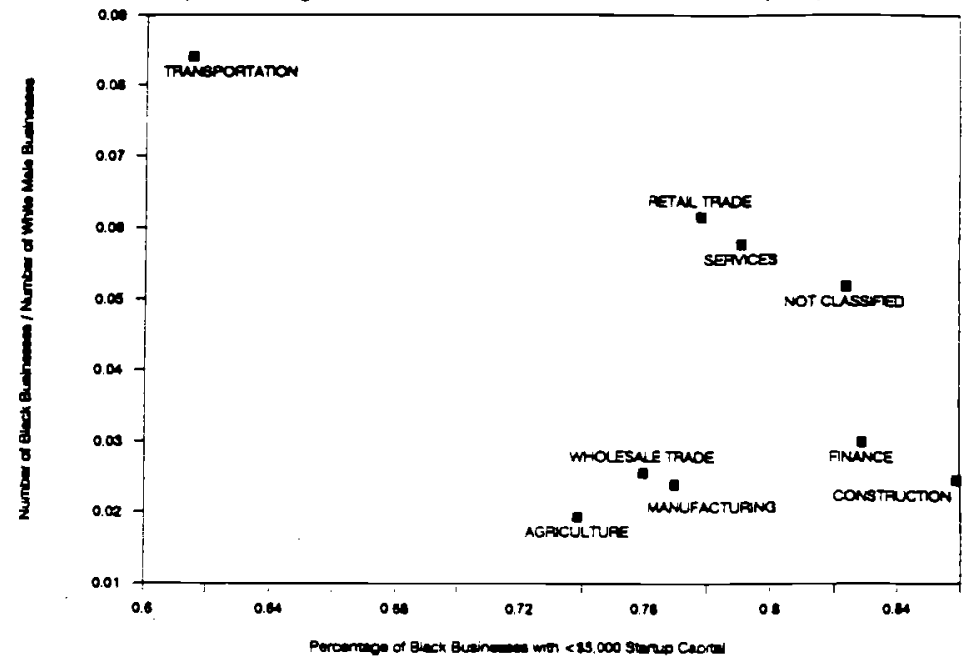

Figure 2

Black / White Ratio of Number of Businesses, for 2-Digit Industries By Percentage of Black Businesses with $<\$ 5,000$ Startup Capital

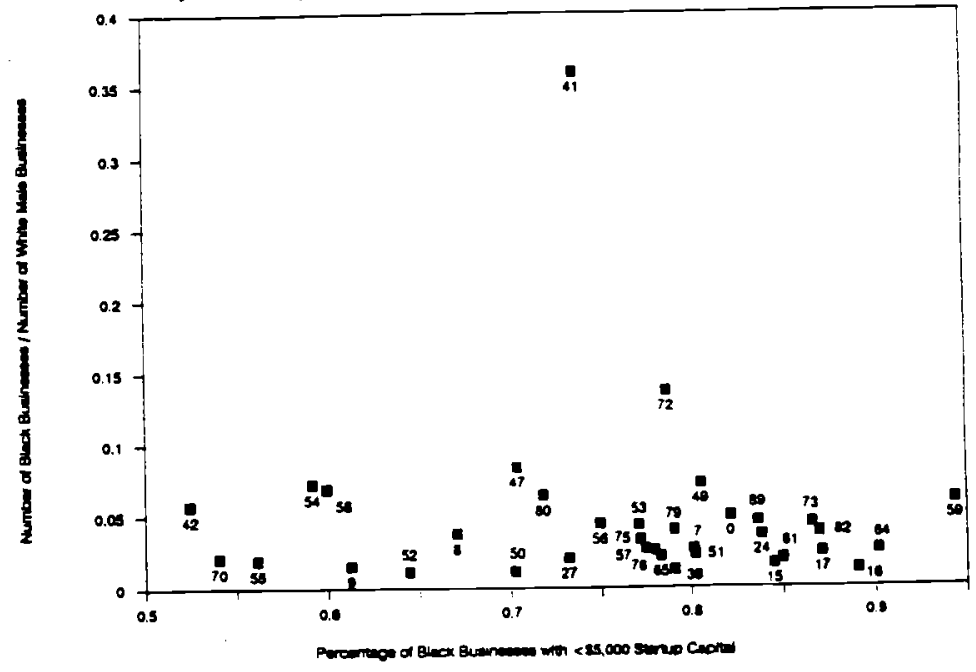


Figure 3

Black / White Ratio of Number of Businesses, for 2-Digit Industries, Excluding SIC 41

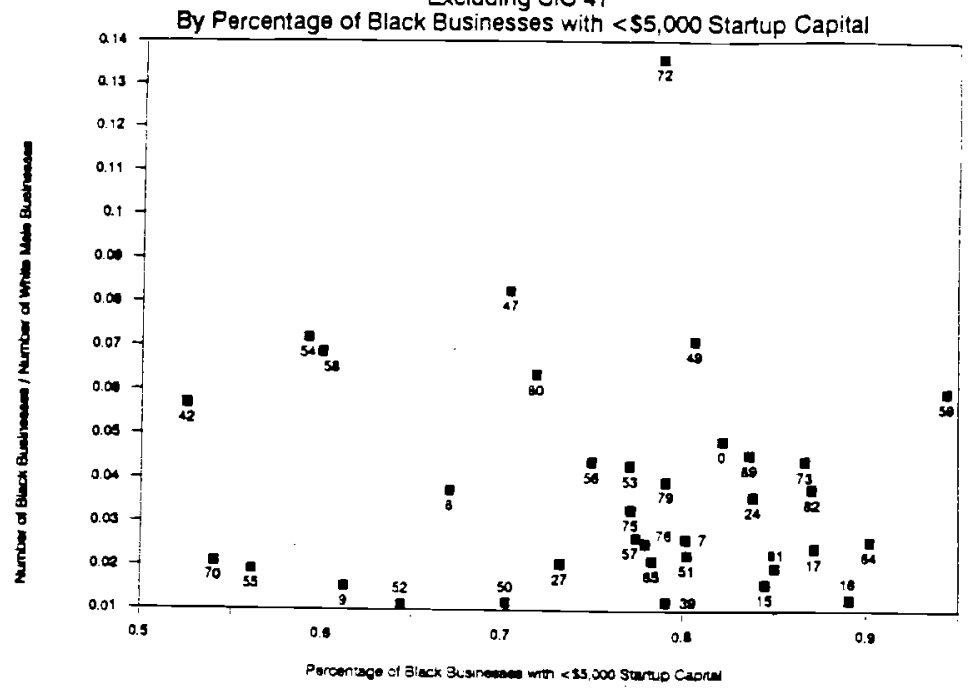

Eigure 4

Black / White Ratio of Number of Businesses, for 2-Digit Industries

By Percentage of White Male Businesses with $<\$ 5,000$ Startup Capital

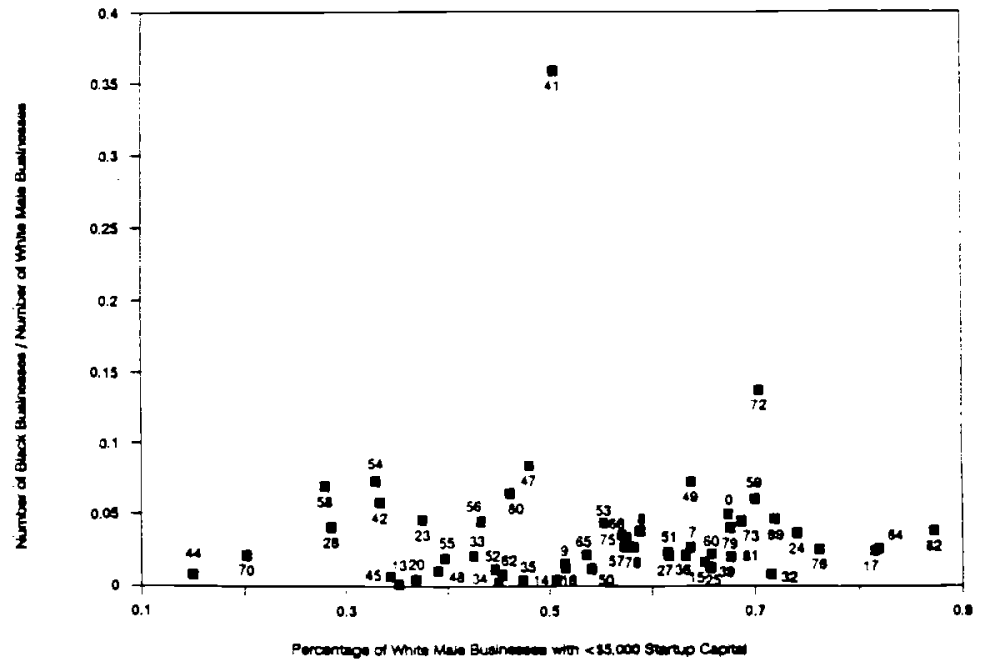


F1gure 5

Black / White Ratio of Number of Businesses, for 2-Digit Industries,

Excluding SIC 41

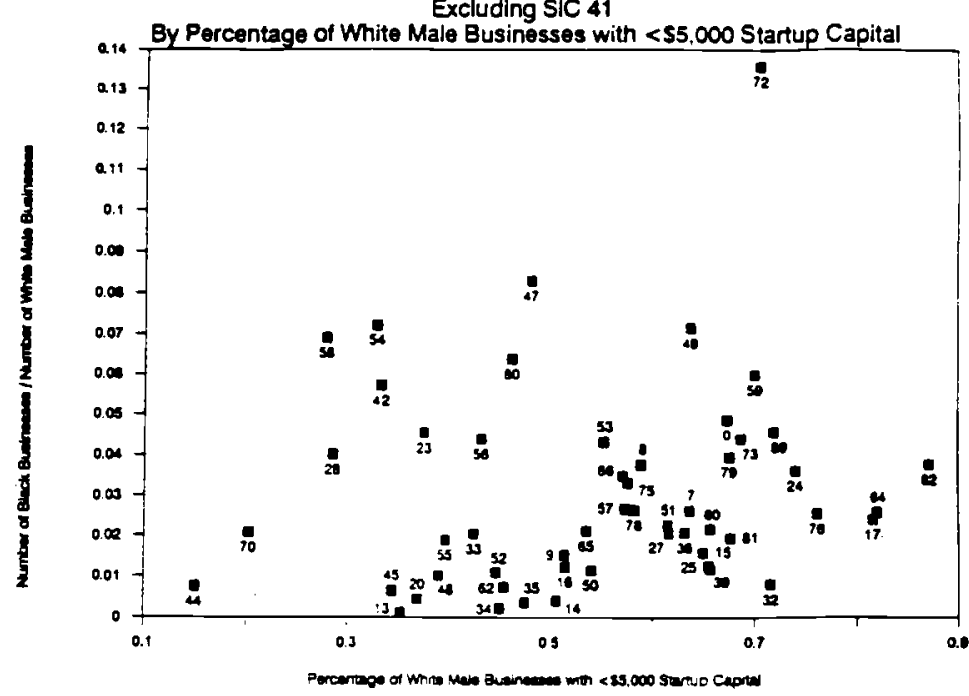

Figure 6

Black / White Ratio of Number of Businesses, for 1-Digit Industries By Percentage of Black Businesses with Primarily Minority Customers

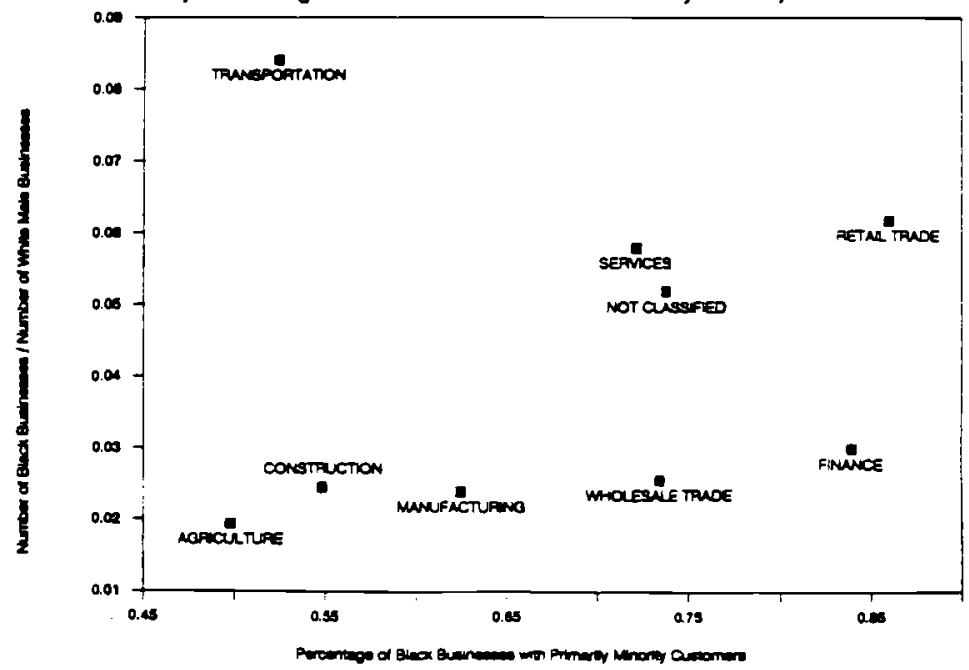


F1gure 7

Black / White Ratio of Number of Businesses, for 2-Digit Industries

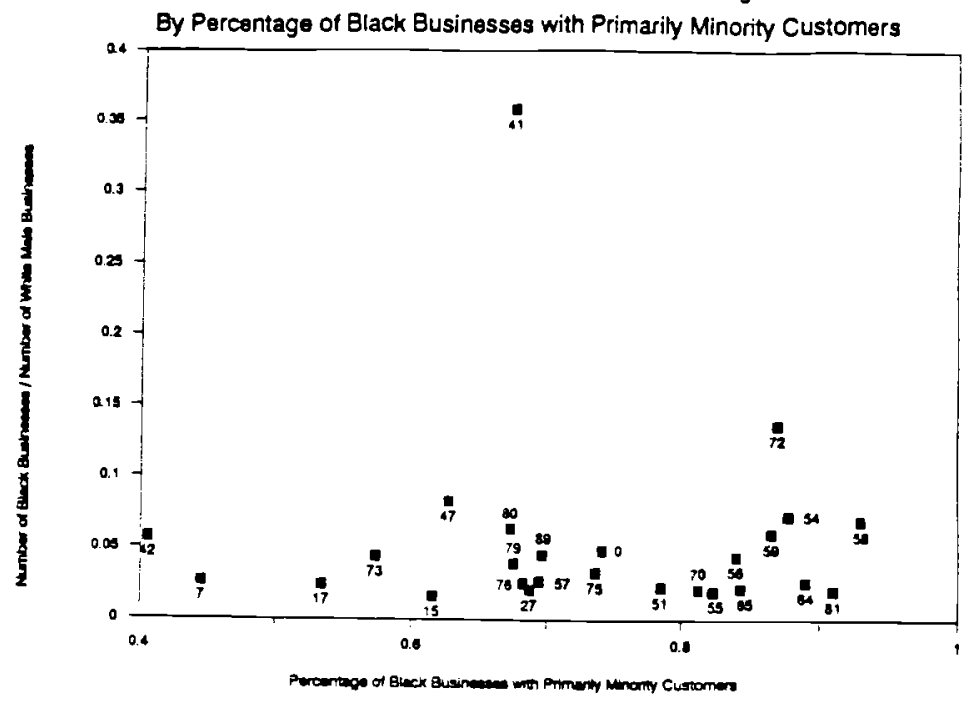

Flgure 8

Black / White Ratio of Number of Businesses, for 2-Digit Industries

Excluding SIC 41

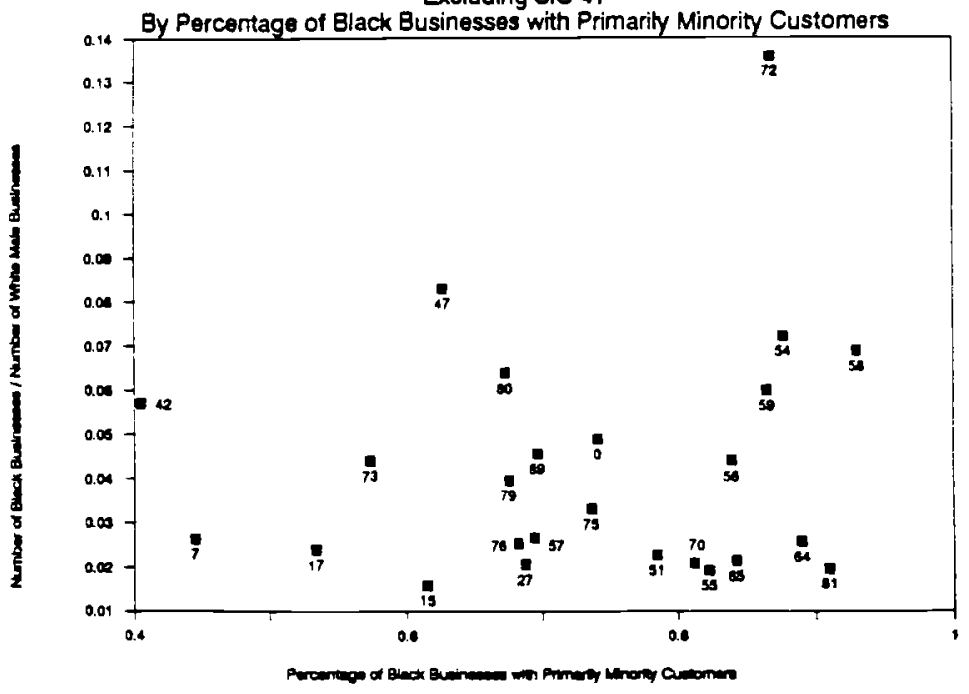




\section{F1gure 9}

Black / White Ratio of Number of Businesses, for 2-Digit Industries By Percentage of White Male Businesses with Primarily Minority Customers

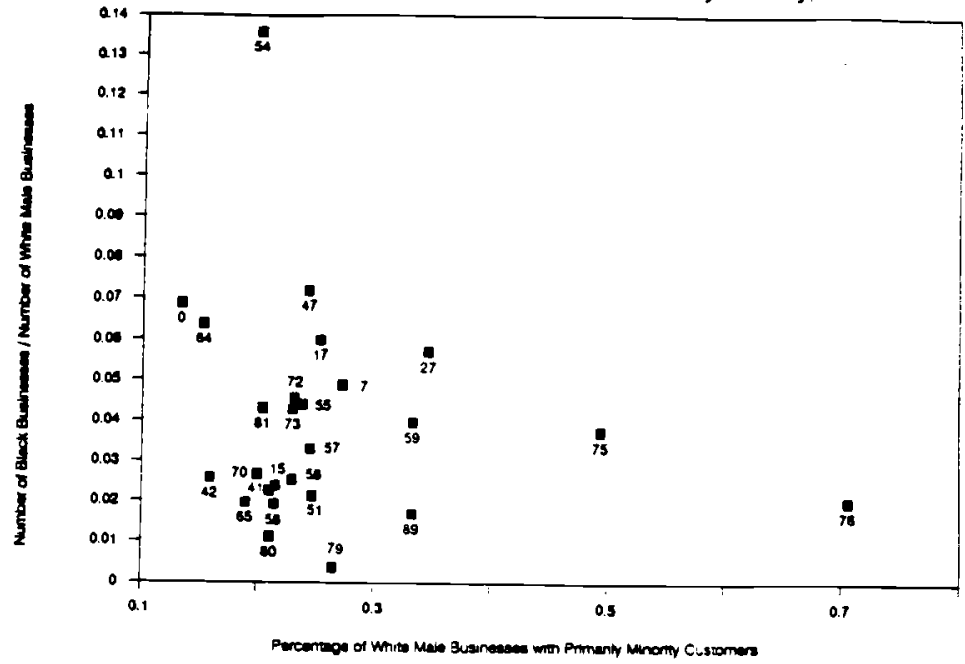

Figure 10

Black / Whito Ratio of Mean Net income, for 1-Digit Industries By Percentage of Black Businesses with $<\$ 5,000$ Startup Capital

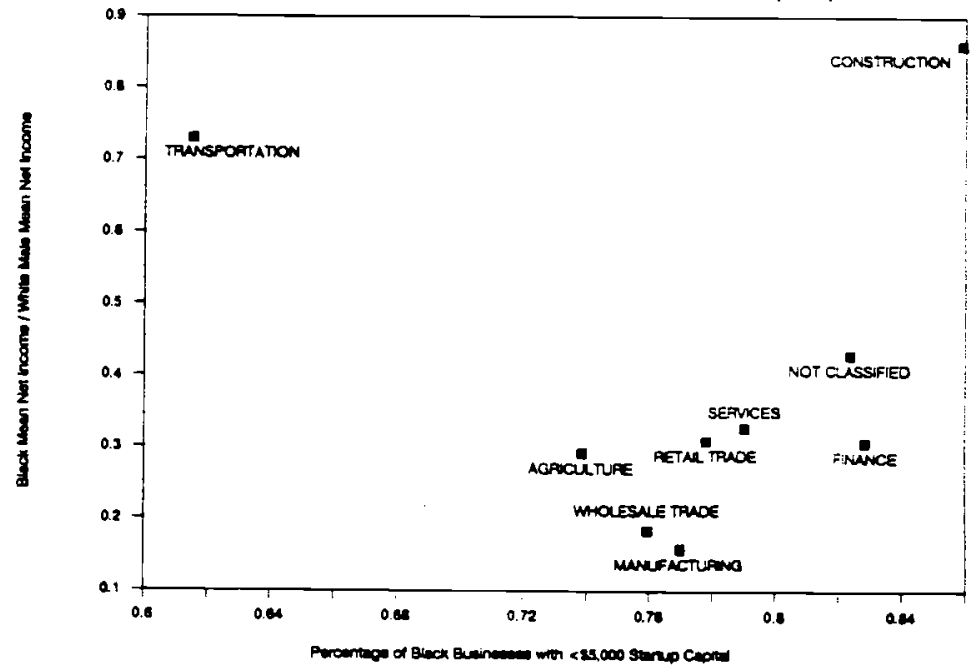


FIgure 11

Black / White Ratio of Mean Net income, for 1-Digit Industries

By Percentage of Black Businesses with Primarily Minority Customers

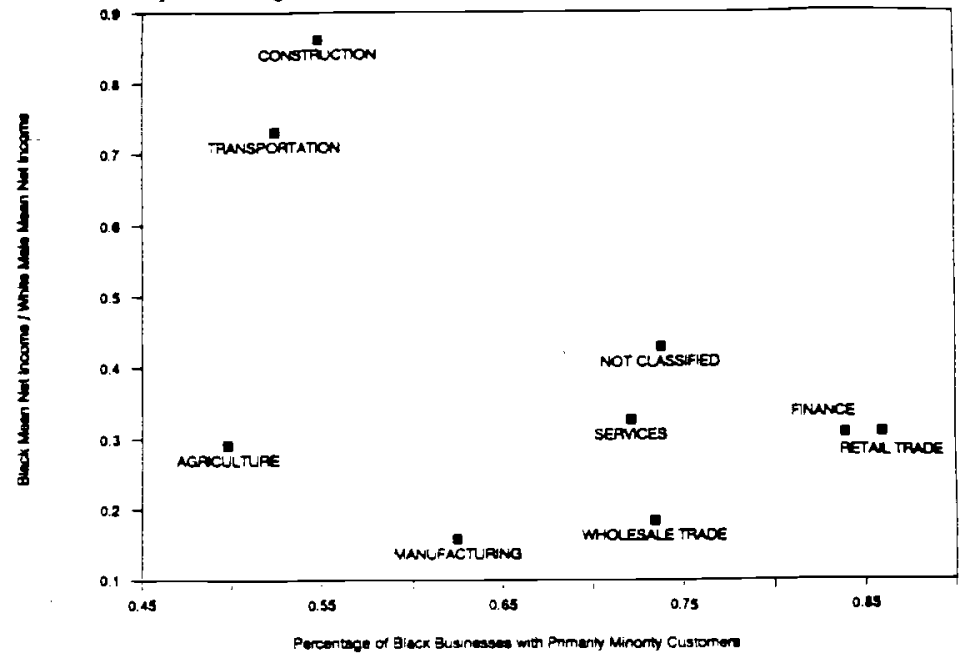

Figure 12

Black / White Ratio of Mean Net Income, for 1-Digit Industries

By Mean Capital Needed to Start Business for Black Businesses

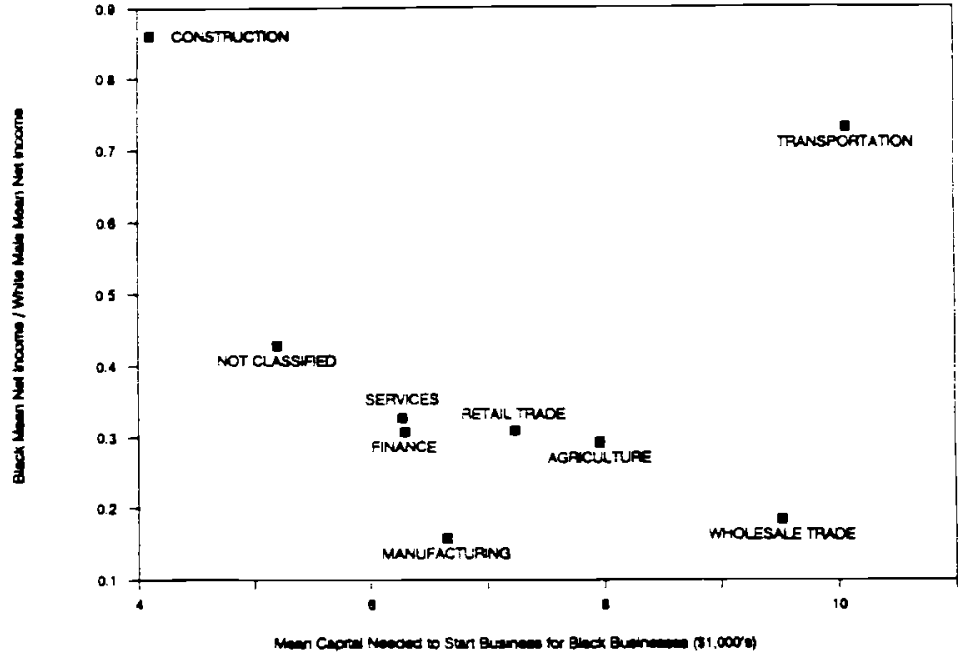

